\title{
Turista Aprendiz na Amazônia: a invenção no texto e na imagem
}

Telê Ancona Lopez

Instituto de Estudos Brasileiros da

Universidade de São Paulo

RESUMO: O objeto deste estudo é o escritor Mário de Andrade (1 893-1945) em sua experiência de fotógrafo moderno, durante sua permanência no Norte, especialmente na Amazônia, em 1927, na primeira das duas grandes viagens do Turista Aprendiz pelo Brasil. Analisa o processo criativo no qual as imagens da Codaque constituem o diário imagético dos negativos e positivos que se justapõe ao diário das legendas e ao do texto onde se desenvolvem as impressões do viajante e a invenção do ficcionista. Aponta também certos vínculos da fotografia produzida nessa viagem com as leituras, a poesia e a ficção andradiana.

PALAVRAS-CHAVE: Mário de Andrade. Diários de viagem. Modernismo brasileiro. Fotografia moderna.

ABSTRACT: The object of this study is Brazilian writer Mário de Andrade (1893-1945) in his experience as a modern photographer, during his stay in the Northern region of Brazil, specially in the Amazon region, during the first of his two long Apprentice Tourist trips throughout Brazil in 1927. The author analyses the creative process by which the Codaque's images constitute the prints and negatives image diary that overlaps with the diary of legends and of text where the traveller's impressions and the fictionist's invention are developed. The article highlights certain links between the photography produced in this trip and Andrade's readings, poetry and fiction.

KEYWORDS: Mário de Andrade. Travel Journals. Brazilian Modernism. Modern Photography.

Mário de Andrade (São Paulo, 1893-1945), fotógrafo moderno, mas de reconhecimento tardio, é a parte que me cabe na jornada "Representações do Brasil: da viagem moderna às coleções fotográficas". Como esse tema é muito amplo, vou restringir-me à fotografia na primeira das duas viagens em que ele se denomina Turista Aprendiz. Essa viagem, ao Norte do país, além de nos 
1. Embora as primeiras fotos no tamanho $6,1 \mathrm{~cm} \mathrm{x}$ $3,7 \mathrm{~cm}$ tragam legendas na letra de Mário de Andrade, identificando-as e datando-as de 1923 e 1925, o fato de serem apenas 22 documentos $\mathrm{e}$ de não se associarem a negativos, as coloca na categoria de cópias recebidas como recordação. Retratam férias em Araraquara, no interior do Estado de São Paulo, na fazenda de parentes, nos últimos dias de junho e no princípio de julho desse ano de 1923 (10 documentos), bem como em julho de 1925 (cinco documentos), nas quais o hóspede está acompanhado de primos ou sozinho. Captam instantes de alegria e manifestam apenas um bom enquadramento.

2.A variação das medidas está apenas nos milímetros e depende do corte das reproduções.

3. Charlot de L. Delluc (1921) ou a análise de Céline Arnaut em L'Action (1922) respaldam os comentários que Mário leva para Klaxon: mensário de arte moderna, ns. 3 e 5 em 15/7 e 15/9 de 1922, como J.M.em "Uma lição de Carlito" e M. de A. em "Ainda O garoto".

4.Texto assinado como R. de M.em Klaxon, n. 2,em 15/6/1922. oferecer o début do fotógrafo empenhado em desvendar seu trabalho em mais detalhes do que na segunda, ao Nordeste, parece-me, ao lado de outros méritos, mais rica em termos da fotografia. Ocorre em 1927, quando Mário, aos 34 anos, por sua obra de poeta, ficcionista, teórico do Modernismo, cronista e crítico, já goza de certa projeção nacional. A escolha do ano de 1927 abre exceção a duas fotos de 1928-1929, dada a importância delas para esta reflexão.

No arquivo do escritor, no Instituto de Estudos Brasileiros da Universidade de São Paulo, na série Fotografias, entre as subséries ali organizadas, sobressai aquela que o caracteriza como um fotógrafo moderno, manejando uma Kodak de caixão, pelo que se observa no auto-retrato enquanto sombra, datado do ano-novo de 1928, no qual nos deteremos mais tarde. Circunscrita a um período de curta duração (1927-1929), a subsérie Mário de Andrade fotógrafo reúne 1.538 imagens em positivo e um número expressivo de negativos'. Os positivos, em preto-e-branco, medem, a maioria, $6,1 \mathrm{~cm} \times 3,7$ $\mathrm{cm}$, e admitem diversas ampliações de $17,5 \mathrm{~cm} \times 12,5 \mathrm{~cm}$, em PB assim como em viragens sépia ou avermelhadas².

Penso que se pode procurar a gênese do fotógrafo no esforço de atualização que a biblioteca do crítico e teórico do Modernismo reflete na área das artes plásticas e na do cinema. Em suas estantes, em 1919, aparece a revista de Darmstadt, Deutsche Kunst und Dekoration, que the exibe excelentes fotos, Le Cinéma de Ernest Coustet (1921), artigos de L. Delluc ou de Céline Arnaud, na revista L'Esprit Nouveau, entre 1922 e 1923, bem como ensaios de ambos que têm por objeto o Charlot, de Chaplin, num enfoque rigorosamente cinematográfico. Ao que se entende, com eles dialogam os comentários sobre The kid, que Mário assina em Klaxon, no mesmo ano da Semana de Arte Moderna, 1922 ${ }^{3}$. Nessa revista do Modernismo de São Paulo, na qual, com suas próprias iniciais ou como J. M. e R. de M., faz crítica de cinema, iá se esboça o namoro com a arte de Daguerre. É então que, pioneiro, valorizando nossa cinematografia nascente, assim se expressa sobre a comédia Do Rio a São Paulo para casar: "Fotografia nítida, bem focalizada. Aquelas cenas noturnas foram tiradas ao meio-dia com sol brasileiro... Filmadas à tardinha, o rosado não sendo tão fotogênico, a produção sairia suficientemente escura. Isso enquanto a Empresa não consegue filmar à noite" 4 .

Apesar da L'Esprit Nouveau não cultivar especialmente a fotografia, a presença dela, nas estantes de Mário de Andrade, sinaliza a educação do olhar do leitor perspicaz que se depara, por exemplo, no n. 21 , de fevereiro de 1924, com Ozenfant e Jeanneret postulando, juntos, a "Formation de l'optique moderne". Esse leitor, em 1923, já definira como "cinematográfico" o romance/idílio estruturado no encadeamento das cenas, sem divisão em capítulos, Fräulein, que vinha escrevendo, no qual trabalhará até a publicação, em 1927, sob o título Amar, verbo intransitivo. Pode-se então pensar que a necessidade de apreender a geometria na disposição dos objetos e nas cenas do cotidiano, ressaltada pelo artigo de Ozenfant e Jeanneret, tenha repercutido na criação do olhar sofisticado da heroína de Mário. Mulher culta, de 
sensibilidade moderna, Fräulein, como uma câmera, sabe isolar ângulos, perceber volumes, seguir planos e contornos no espaço da casa da família Sousa Costa.

No arquivo, o exame dos documentos nos faz supor que a série Fotografias procede dos retratos de família e de si próprio, resguardados por Mário a partir da segunda metade da década de 1910. Nesse mesmo período, ao moço autodidata agrada recortar, de jornais e revistas, não só textos como imagens do Brasil, no intento de conhecer sua terra e de constituir um conjunto documental para seu uso. Esses recortes, ao delinear estudos e viagens virtuais por diversas regiões, associam-se, na malha do arquivo, a oito cartões-postais sem mensagem, com vistas de Mariana e São João del-Rei que demarcam uma viagem real e a existência de uma coleção fotográfica. No envelope que os conservava, a nota manuscrita do colecionador, "Brasil antigo", convalida igualmente a finalidade de estudos. As cidades mineiras fotografadas e o fato dos postais serem graficamente mais antigos trazem à baila as férias de Mário de Andrade, em julho de 1919, quando, em Mariana, ele visita Alphonsus de Guimaraens e conta, ao simbolista da sua admiração, estar se preparando para fazer conferências 5 . Nesse mesmo ano, a crônica "Alphonsus" sai em 1ํㅡㄹ novembro na revista paulistana A Cigarra, ilustrada com a fotografia da Igreja de S. Francisco de um dos cartões, aliás, com duplicata na coleção․ Em 1920, a Revista do Brasil estampa, dividida em quatro partes, "A arte religiosa no Brasil", conferência na Congregação da Imaculada Conceição de Santa Ifigênia”. Tendo publicado em 1917 Há uma gota de sangue em cada poema, Mário está prestes a se definir como modernista, o que ocorrerá na série de crônicas De São Paulo, entre novembro de 1920 e maio de $1921^{8}$.

Como se vê, há bastante tempo interessa a Mário de Andrade conhecer seu país. Esse desígnio, por certo, o motiva a voltar a Minas Gerais, na Semana Santa de 1924. Com Oswald de Andrade, Tarsila do Amaral, o poeta francês Blaise Cendrars, Olívia Guedes Penteado, grande dama da aristocracia do café e mecenas dos modernistas, e outros amigos, participa da "viagem da descoberta do Brasil", assim nomeada pelo crítico Alexandre Eulálio?. Fundamental nos rumos do nosso nacionalismo modernista, a viagem tem, entre outros importantes resultados, o Noturno de Belo Horizonte, longo poema de Mário no qual as visões do eu lírico transfiguram caminhos do viajante que deixa, também no desenho e na crônica, flagrantes de seu percurso ${ }^{10}$. E que testemunha o gosto de fotografar na amiga que assim se registra num hotel: "D. Olívia Guedes Penteado, solteira, photographer, anglaise, London", em meio ao "o claro riso dos modernos"11.

Logo depois de setembro de 1924, pelo que se pode analisar, tem início o contato mais direto de Mário de Andrade com a arte fotográfica: ele passa a receber, mediante assinatura, Der Querschnitt, revista de Berlim ligada à Nova Objetividade. Ali, nas reproduções de fotos de Man Ray, Riebicke, Schneider, Galloway e outros, multiplicam-se lições de composição de autor, consignando o corte, o valor do close, matizes para o melhor rendimento do preto-e-branco, a sugestão de cores, geometrizações, o aproveitamento da luz e da sombra, o reflexo, o movimento, o retrato de costas, a plena liberdade
5. GUIMARAENS FILHO, 1974. À p. 29, a nota 27 do organizador transcreve carta do pai, de $15 / 7 / 1919$, relatando os propósitos da viagem de seu visitante.

6. A crônica vem de $A C i$ garra, São Paulo, n. 123, ano $6,1 / 11 / 1919$.

7.Ver a edição anotada de Claudete Kronbauer de ANDRADE, 1993, onde se recupera a publicação na Revista do Brasil, n. 49, 50, 52, 54, São Paulo/Rio de Janeiro, 1920.A série divide-se em "O Triumpho Eucharistico de 1733. Conferência realizada na Congregação da I. C. de Sta. Ephigenia" (n. 49, p. 5-12);"Arte Christã" (n. 50, p. 95-103); [Rio de Janeiro] (n. 52, p. 289293); "Em Minas Geraes" (n. 54, p. 102-111).

8.As crônicas, publicadas na revista carioca Ilustração Brasileira entre novembro de 1920 e maio de 1921, saíram na edição anotada de Telê Ancona Lopez, em 2004.

9. EULÁLIO, 1978.

10. O poema, escrito em 1924, foi publicado em Clã do jabuti, em 1927. São seis os desenhos em folhas milimetradas de caderninho de bolso (ver Coleção de artes de Mário de Andrade, IEB-USP); a VIII das "Crônicas de Malazarte" focaliza a excursão na América brasileira. Rio de Janeiro, maio de 1924 .

11. EULÁlIO, op. cit., p. 277; registro dos hóspedes no Hotel Macedo de São João del-Rei, em 16/4/1924. 
12. O ano de 1926 pode ser considerado como o ano da aquisição de quatro volumes da obra de Koch-Grünberg e da leitura, bem como do início da criação de Macunaí$m a$, nas margens do segundo volume de Vom Roroima zum Orinoco: Myten und Legenden der Taulipang und Arekuná Indianer. É possível que tenha, então, comprado a obra completa em cinco volumes, da qual o quarto desapareceu, ou reunido, como conseguiu, os volumes que continuaram em suas estantes: v I, edição de Berlim, Dietrich Reimer, 1917; v. II, Stuttgart, Strecker und Schröder, 1924; v. III e V, tirados por esta última editora, ambos em 1923.

13. MELLO, 1991, p. 35. para a experimentação, enfim. Der Querschnitt abre, para o sôfrego leitor, a capacidade da câmara expressar o humor, o lirismo, a poesia visual, a cena cômica; de recriar a alegria, a espontaneidade do cotidiano; de construir o retrato como o instante iluminado que recolhe a alma de homens e mulheres ou que com eles inventa personagens para propor situações existenciais novas, surpreendentes, como o pintor Braque de ponta-cabeça. Ensina-the, principalmente, que a máquina é a companheira inseparável do viajante e de todos aqueles que empreendem pesquisas de campo etnográficas ou etnológicas.

Nessa direção, as lições proporcionadas por Der Querschnitt casamse com aquelas que o modernista brasileiro recebe de Theodor Koch-Grünberg em 1926, nos quatro volumes que possui da obra magna Vom Roroima zum Orinoco $^{12}$. Em Koch-Grünberg, além do lendário do segundo volume, matriz do poema Lenda das mulheres de peito chato e da rapsódia Macunaíma, iniciada nesse ano nas margens do exemplar, Mário de Andrade acompanha um longo e rigoroso ensaio fotográfico que documenta, no correr dos volumes, o tipo físico, costumes e elementos da cultura material dos diferentes povos indígenas estudados, bem como o espaço geográfico e o próprio etnólogo em atividade. O ano da leitura de Vom Roroima e o primórdio da escritura de Macunaíma nos são fornecidos pelo próprio escritor, de forma cifrada, na data que encima a "Carta pras icamiabas", capítulo IX: "Trinta de Maio de Mil Novecentos e vinte e seis, em São Paulo".

Aliás, em 1926, na carta de 26 de julho, enviada por Mário a Luís da Câmara Cascudo, percebe-se que fotografia, coleção e intenções viajoras combinam-se no horizonte do remetente:

Você nem imagina que gosto me deu o campeiro vestido de couro que você me mandou. Andei mostrando pra toda gente e mais a fotografia do maravilhoso cacto. As três fotografias já estão bem guardadinhas na minha coleção. Se lembre sempre de mim quando vir fotografias da nossa terra aí dos seus lados. Meu Deus! Tem momentos em que eu tenho fome, fome estomacal de Brasil agora. Até que enfim sinto que é dele que me alimento! Ah! se eu pudesse nem carecia você me convidar, já faz sentido que tinha ido por essas bandas do norte visitar vocês e ao norte ${ }^{13}$.

A viagem no texto e na Codaque

Mário de Andrade vai primeiramente ao Norte. As duas viagens que realiza como Turista Aprendiz, em 1927 e 1928-1929, são as mais demoradas e extensas de uma vida de poucas viagens. Devotadas a uma espécie de impregnação do Brasil, ambas the rendem diários textuais e imagéticos, estes últimos unindo legendas às fotografias. Na primeira, entre maio e princípio de agosto de 1927, ao lado de D. Olívia Penteado, na verdade, a responsável pela idéia, e de duas mocinhas, a sobrinha dela, Margarida Guedes Nogueira 
- Mag - e a filha da pintora Tarsila do Amaral, Dulce do Amaral Pinto - Dolur -, retroceder visita os Estados do Amazonas e do Pará, chega a Porto Velho, a lquitos, no Peru, e à fronteira com a Bolívia. Vai e volta de vapor, com escalas nos portos principais; a bordo de embarcações típicas da região, navega os grandes rios, igapós e igarapés; toma um trem da Madeira-Mamoré. Na segunda, ao Nordeste, do final de 1928 até fevereiro no ano seguinte, anda por Alagoas, Rio Grande do Norte, Paraíba e Pernambuco.

O diário, durante a viagem à Amazônia, em 1927, dispersa-se em muitos fólios de variado feitio, conforme nos conta a última versão de vida do texto, datada de 1943:
Estas notas de diário são sínteses absurdas, apenas pra uso pessoal, jogadas num anuariozinho de bolso, me dado no Lóide Brasileiro, que só tem cinco linhas pra cada dia. As literatices são jogadas noutro caderninho em branco, em papéis de cartas, costas de contas, margens de jornais, qualquer coisa serve. Jogadas. Sem o menor cuidado. Veremos o que se pode fazer com isso em São Paulo ${ }^{14}$.

A análise dos documentos do processo criativo aponta quatro diários. Dois, no decorrer da viagem. Este, acima citado, conjunto de textos espalhados em papéis diversos, coexistiu com um segundo, imagético-textual, constituído dos negativos vinculados, ao que se supõe, a um caderninho de bolso, onde o fotógrafo teria feito de imediato, a lápis preto, anotações relativas às tomadas que concretizava com sua câmera. Vale dizer, informações de ordem técnica, rápido registro de locais, pessoas e talvez de outros dados, visando à precisão do testemunho no momento de legendar as imagens copiadas em São Paulo. Caderninho que, missão cumprida, foi por ele descartado.

Ao regressar, o escritor e fotógrafo, ainda em 1927, lança-se em mais dois diários: o imagético-textual e o textual propriamente dito. $\bigcirc$ primeiro compõe-se de mais de 500 imagens reveladas em preto-e-branco e viragens, seguidas das respectivas legendas no verso, a lápis. Estas, em uma primeira etapa da escritura, geralmente transpõem apenas as informações colhidas in loco, mas, em uma segunda-materializada no traço mais leve -, glosam as representações e o exercício fotográfico, ao construir um texto fragmentário, multifacetado e híbrido, como todos os diários. Nele viceja tanto o registro que se propõe fidedigno como a criação literária que exerce o humor, o lirismo e a metalinguagem.

Diário moderno, junto com o primeiro, aquele das sínteses esboçadas em papéis esparsos, embasa o trabalho do escritor que, em sua escrivaninha paulistana, no mesmo ano da viagem, expande um novo texto, no qual recorre a diversos tipos de relato e dialoga com o diário da viagem do naturalista Martius pela Amazônia ${ }^{15}$. Tem intenção de publicá-lo como $\bigcirc$ Turista Aprendiz: (Viagem pelo Amazonas até o Peru, pelo Madeira até a Bolívia e por Marajó até dizer chega), paródia ao título do livro do avô, Leite Moraes, de 1883, Apontamentos de viagem de São Paulo á capital de Goiás, desta ao Pará, pelos rios Araguaia
14. ANDRADE, 1976, p. 64.

15. SPIX; MARTIUS, 18231831. Obra na biblioteca de Mário de Andrade com notas a lápis dele. Entre os Manuscritos Mário de Andrade está uma tradução do nascer do dia amazônico na obra de Martius, matriz da alvorada no diário do Turista Aprendiz. 
16."Desgeograficar"é expressão cunhada por Mário de Andrade quando da apresentação de suas propostas de modernidade e nacionalismo no segundo prefácio para $\mathrm{Ma}$ cunaíma, 1928. Ver edições críticas da obra, Coleção Archives, 1988, 1996

17. COLI, 2005 e Tocantins, e do Pará á Corte. Considerações administrativas e políticas. Dessa versão de 1927, restaram parcelas aproveitadas na versão final em datiloscrito, precedida do prefácio de 30 de dezembro de 1943. Curiosamente, prefácio e texto não prevêem a inclusão de fotografias no livro planejado.

"Crônica do cotidiano", no dizer de Girard, ou "ancoragem no tempo", segundo C. Viollet e bem mais que isso, o diário final do Turista Aprendiz, moderno e nacionalista de olhos postos no universal, em muitas seqüências supera o registro da realidade do espaço, característica usual dos diários de viagem. Assim acontece porque, ao enveredar pela ficção, prefere um trajeto à moda do barão de Münchhausen. Faz do narrador o protagonista da transviagem da invenção que the faculta de cruzar um espaço de feições surrealistas, no intuito de figurar, com humor, no estranhamento, a hipérbole natural da natureza amazônica, desprezando o regionalismo de cunho apologético. A transviagem permite ao diarista, paradoxalmente, a viagem ao redor de suas leituras, quando ele logra, na recriação de relatos de outros viajantes, justapor irreverência e discurso elevado, ao transitar por um espaço de invenção, "desgeograficado" (conforme classificação sua no Prefácio a Macunaíma), contendo elementos do Brasil, da América, da Europa e da África ${ }^{16}$.

Turista Aprendiz, diário textual publicado, contém diversas alusões à câmera, cuja marca é abrasileirada para Codaque, e ao ato de fotografar, criado o neologismo "fotar". Caminha paralelo ao diário na fotografia, ambos multifacetados, mais um traje de arlequim no modo de Mário de Andrade estruturar suas obras. O diário imagético, aquele que aqui nos interessa, consolida a experimentação, vincada por um forte senso da composição, apoiada no conhecimento técnico. Configura a incursão consciente pela fotografia como linguagem, a redefinição do olhar através da lente, sabendo que "nenhum fotógrafo oferece uma imagem natural: o que ele produz com sua câmera é sempre construção que recorta, enquadra, valoriza ou diminui aspectos representados do mundo", conforme sublinha hoje o crítico Jorge Coli ${ }^{17}$.

Mário fotógrafo subverte planos, pratica o close; calcula, compõe; despreza padrões ao fazer cortes ou tomar figuras de costas. Grava sutilezas, como no desfile escolar em Porto Velho, em que o semicírculo dos chapéus e do guarda-sol de D. Olívia é arremedado pela copa das árvores. Imprime um "clima" à fotografia. Desenvolve seqüências de acordo com a movimentação da luz, da cena, quase cinema, como nas fotos do pescador que arremessa a tarrafa. E anota, de imediato, seu propósito para cada imagem, bem como as condições em que o trabalho se processa, para depois agregar esses apontamentos às legendas, no verso dos positivos: luz - "sol" -, abertura do diafragma, hora e minutos exatos (Figuras 1 e 2). 
Cara telado

da Amadeira-Inomare'

Partivelno-71-VI-27

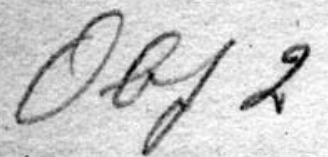

foll

$13+10$

265

Figura 1 - "Casa telada da/Madeira-Mamoré/Porto Velho - 11 /VI-27/Obj. 2 Sol

1/13 e 10." Acervo do Instituto de Estudos Brasileiros da Universidade de São Paulo.

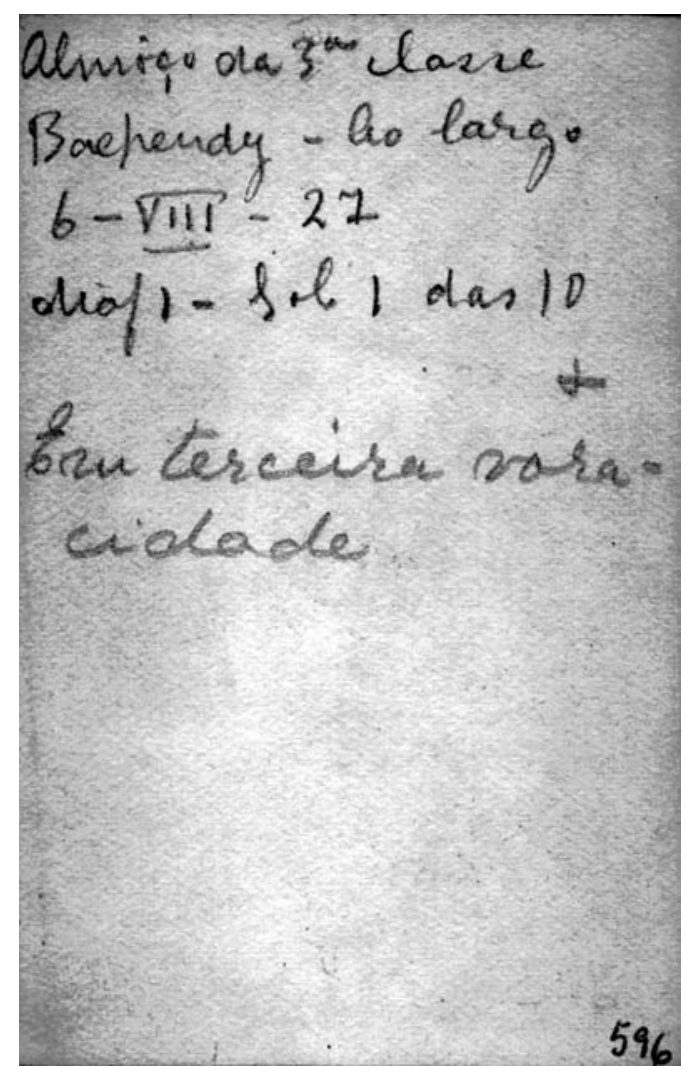

Figura 2 - "Almoço da 3ª Classe. Baependy - ao largo/6-VIII-27/diaf. 1 - Sol 1 das 10 Em terceira voracidade". Acervo do Instituto de Estudos Brasileiros da Universidade de São Paulo. 
18. No diário: " 18 de maio", ANDRADE, 1976, p. 60 .

19.Verso $10^{\circ}$, final, do poema "O trovador" de Paulicéia desvairada. São Paulo, ed. do A. na Casa Mayença, 1922. O ensaio da crítica norte-americana Esther Gebara, "'Nunca olhei tão olhado em minha vida e está sublime' o (auto)-retrato de Mário de Andrade", põe a "Aposta de ridículo" na esfera da sátira. Ver GEBARA In: SÜSSSEKIND; DIAS, 2004 p. $169-190$.
Vertentes

O diário das imagens e legendas, que funde testemunho e artefazer, possui vertentes que se interpenetram, concernindo ao registro do cotidiano do grupo de amigos, do espaço e da vida do homem na Amazônia, assim como àquela dimensão que põe Mário de Andrade em destaque - a experimentação artística.

cotidiano do quarteto excursionista - instantâneos, poses e retratos - circunscreve-se ao Turista Aprendiz e suas companheiras, apanhando por vezes outros companheiros de viagem. Desdobra-se na ficção vivida como lazer: o turista e a filha de Tarsila se fantasiam de índio, incorporando legendas jocosas; Mário se arranja especialmente para uma "Aposta de ridículo" em Tefé, a 12 de junho, de luvas, leque, comendo banana, e suas três companheiras se convertem em personagens. Assim, D. Olívia, objeto da amizade reverente do modernista, é cognominada Nossa Senhora do Brasil e Manacá, flor discreta, perfumada; Dolur se torna Trombeta, e Mag, Balança, por conta de uma brincadeira envolvendo a questão do Juízo Final.

Nessa vertente, os auto-retratos de Mário, na referida aposta e em Assacaio, em 17 de junho, são bastante significativos. Preludiam - cheios de humor - uma espécie de adesão à civilização tropical por ele postulada em Belém, no dia 18 de maio de 1927:

Há uma espécie de sensação fincada da insuficiência, da sarapintação, que me estraga todo o europeu cinzento e bem arranjadinho que ainda tenho dentro de mim. Por enquanto, o que mais me parece é que tanto a natureza como a vida destes lugares foram feitos muito às pressas, com excesso de castro-alves. E esta pré-noção invencível, mas invencível, de que o Brasil, em vez de se utilizar da África e da Índia que teve em si, desperdiçou-as, enfeitando com elas apenas a sua fisionomia, suas epidermes, sambas, maracatus, trajes, cores, vocabulários, quitutes... E deixou-se ficar, por dentro, justamente naquilo que, pelo clima, pela raça, alimentação, tudo, não poderá nunca ser, mas macaquear, a Europa. Nos orgulhamos de ser o único grande (grande?) país tropical.... Isso é o nosso defeito, a nossa impotência. Devíamos pensar, sentir como indianos, chins, gente de Benin, de Java... Talvez então pudéssemos criar cultura e civilização próprias. Pelo menos seríamos mais nós, tenho certeza ${ }^{18}$.

São imagens que ampliam o alcance do crivo crítico nacionalista proposto na profissão de fé do poeta, em 1922, "Sou um tupi tangendo um alaúde!"19.

Se em diversas passagens, no datiloscrito concluído em 1943, a crônica do cotidiano deixa transparecer o espanto do olhar europeizado do paulistano diante da desmesura e da singularidade do mundo amazônico, o diário imagético também se instala nessa dimensão. No texto, muito do que, ao viajante, parece inusitado, insólito, ali se reveste da dimensão ficcional, marcada pelo estranhamento que se vale do corriqueiro e apela para o nonsense, para o disparate, como no fragmento que parodia a composição escolar ao apresentar o peixe-boi. Ou na longa seqüência intitulada "Perdidos" - quase um conto -, 
que joga com a escala do tamanho dos excursionistas desorientados na imensidão da floresta e que se liga, na fotografia, ao bem-humorado auto-retrato à Lilliput, no qual o Turista Aprendiz, muito chique, pára, diminuto, diante do tronco da sumaúma gigante. A ficção implícita se repete na pose de Dolur, no mesmo lugar, frágil e miúda, também trajada com elegância. Na verdade, seqüência narrativa e fotos nos permitem imaginar a força da imagem no âmbito da criação do texto. Refiro-me ao estreito relacionamento do texto com a imagem quando da escritura que, em São Paulo, unificou o diário, debruçando-se sobre as notas tomadas in loco, sobre as legendas e as reproduções fotográficas (Figura 3).

Outra vertente da mescla de fotos e legendas é aquela que retém com engenho e arte - a função documental da fotografia ao se voltar para aspectos da geografia física da região, para o homem e a cultura material. Deste modo, a paisagem - a terra, os rios, a vegetação -, a população de brancos, mestiços e indígenas, homens, mulheres, curumins, os meios de transporte, trabalho, usos e costumes são fixados. A profusão de imagens, dentre as quais se pode lembrar o vaqueiro de Marajó, as caiçaras, isto é, os estrados que protegem os bois da voracidade das piranhas, o mogno cortado e numerado, deslizando na corrente, os sacos de sernambi, a pesca de tarrafa, a casa sobre palafitas, a casa de alvenaria telada, a maloca e os índios pintados com jenipapo, o hotel de janelas góticas, as ruínas da igreja de Porto Velho - para selecionar algumas -, recebe, nas legendas, além da identificação e do relatório técnico, o comentário cheio de humor, incluindo por vezes rimas, trocadilhos e a citação de versos de grandes poetas.

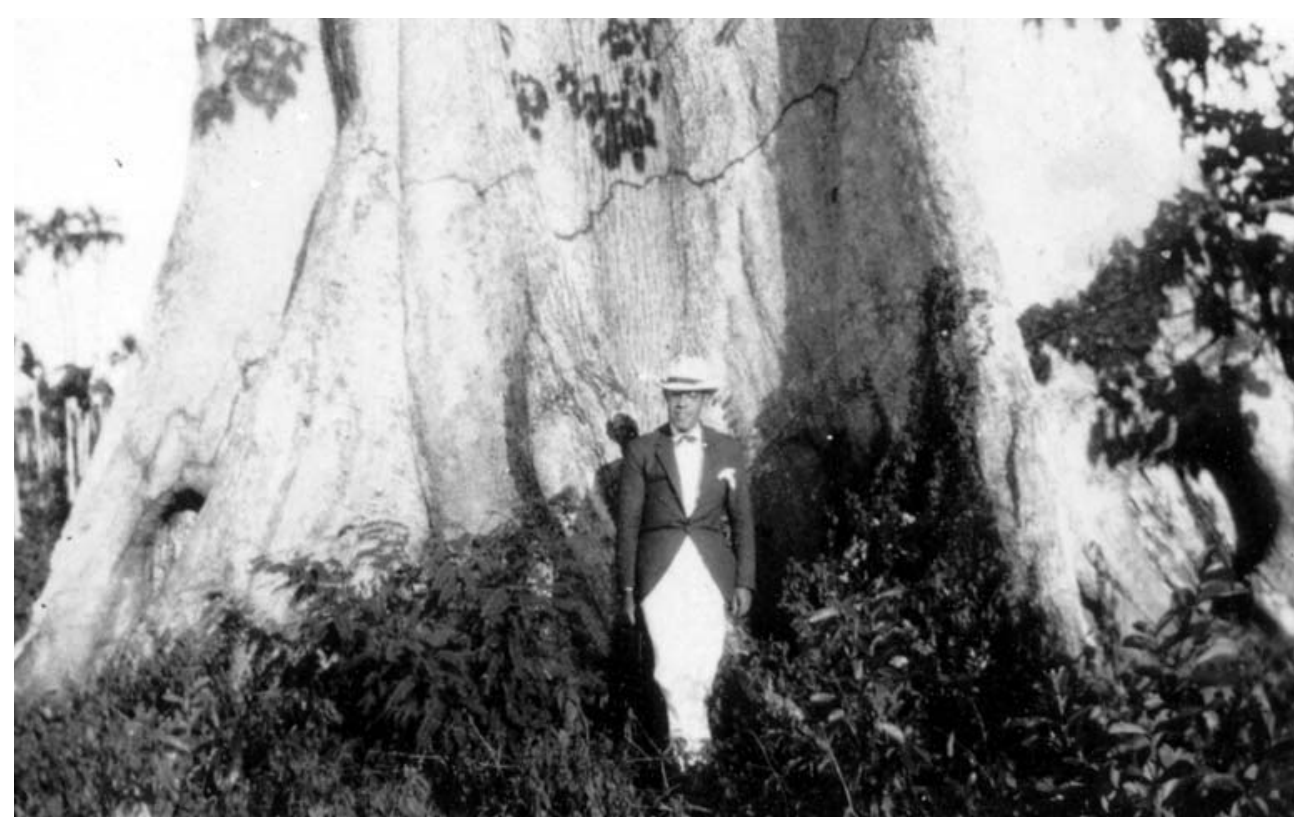

Figura 3 - "Eu diante dum tronco de sumaúma entre Sto. Antônio e Porto-Velho, nos limites entre Amazonas e Mato Grosso/1 1-VII-27/Diaf. 1 Sol 3/16 e 30". Acervo do Instituto de Estudos Brasileiros da Universidade de São Paulo. 
20. ANDRADE, 1976, p. 103.
Mário de Andrade, nessa viagem, não é um pesquisador da vida indígena. Os índios com os quais se defronta, quase todos aculturados, são apenas objeto da admiração ou do espanto do diarista, no texto e na fotografia. Ele assim se manifesta, por exemplo, neste trecho datado de Assacaio, 17 de junho:

Índios legítimos, bancando negros, pintados com jenipapo. Não pintam as articulações dos dedos, que ficam parecendo cicatrizes claras, é horrível. Fotei. Pouco depois do meio-dia portamos em Belém, onde vimos uns índios lindos, principalmente a cunhã tristonha, iá bem mulher, fineza esplêndida de linhas ${ }^{20}$.

E na foto, em cuja legenda está:

"Assacaio/17-Vl-27/ O mais alto é enegrecido pintado de jenipapo".

A falta de recursos técnicos da Codaque impossibilitou, seguramente, a fotografia noturna. As dificuldades de ordem técnica e o desejo de aumentar a documentação iconográfica fundamentam, ao que nos parece, o lote de 24 imagens que complementa a viagem de 1927, na série Fotografias. Retrata indivíduos e aspectos da cultura de nações indígenas, uma caçada de jacaré e a praça principal de lquitos. Com legendas impressas, sete são cartões-postais verdadeiros, da lavra de um profissional. Da máquina de um amador, 17, tendo no verso informações sumárias em autógrafo ou datilografadas, ou não portando legenda, são poses de índios ampliadas como cartões-postais.

Nas vertentes da fotografia andradiana, é preciso destacar especialmente a experimentação artística modernista, a qual, por exemplo, concentra-se na geometria dos mastros dos veleiros em Areia Branca, Mossoró, na rota do regresso, em 6 de agosto, repetindo, de certo modo, os barcos de pesca de Galloway no golfo de Corinto, da Querschnitt de fevereiro daquele ano de 1927. Recorte semelhante, em 1942, afirmaria o grande Nikvist, em $O$ porto, de Bergman, na bela cena em que a aglomeração dos mastros preenche a tela.

Quando o fotógrafo pesa a sua experimentação, isto é, quando analisa a própria arte nas cópias em positivo, dá à legenda, em vários casos, a incumbência de avaliar o resultado. O lápis traça, então, no verso: "Ritmo", "Equilíbrio", "Futurismo pingando" ou "Minha obra-prima" lque é de fato, no flagrante da vitória-régia), e não se esquece de acusar a dupla exposição dos negativos: "Desvairismo por acaso/questão de lancha e de lunch/ 7-VI-27." e "Foto futurista de Mag e Dolur sobrepostas às margens do Amazonas. Junho de 1927. Obsessão."

O olhar do fotógrafo que persegue a dimensão poética harmoniza-se com os estudos de Mário a respeito do Seqüestro da Dona Ausente, os quais, amparados pela psicanálise, esmiúçam esse tema do lirismo amoroso no cancioneiro luso-brasileiro. Quando o vento enfuna no varal os lençóis e levanta as roupas brancas, os volumes e o movimento colhidos pela objetiva sugerem corpos e fazem jus à legenda "Roupas freudianas/Fortaleza, 5-VII-27/Fotografia refoulenta/Refoulement/Sol I diaf. I" (Figura 4). O branco espraia-se pelo areão como a luz intensa do sol que as lentes vêem branco, também. Mário possui, 


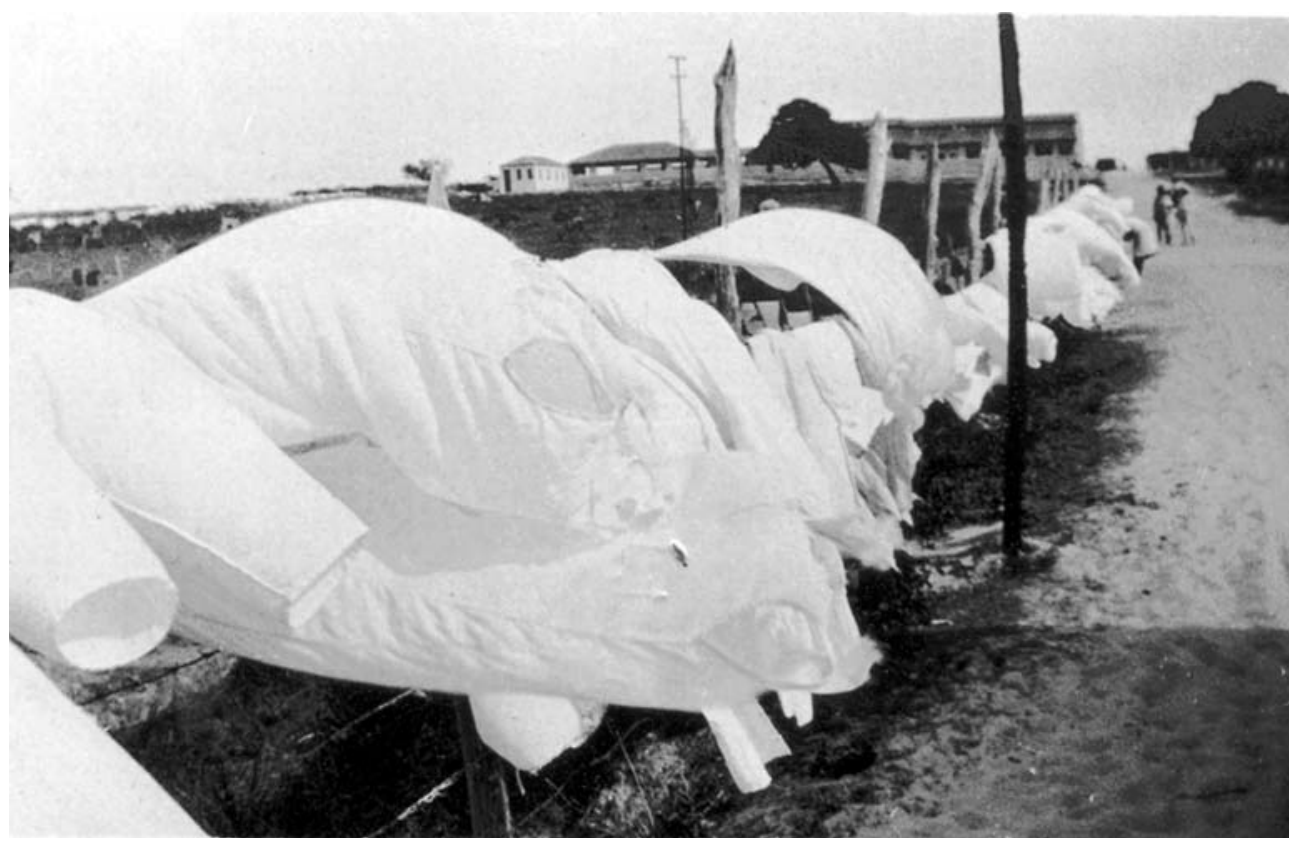

Figura 4 - "Roupas freudianas/Fortaleza, 5-VII-27/Fotografiarefoulenta/Refoulement/Sol I diaf. I". Fotografia de Mário de Andrade. Acervo do Instituto de Estudos Brasileiros da Universidade de São Paulo.

sem dúvida, o dom de "compor o ambiente em que a realidade capitula diante da luz e se converte em uma expressão sugestiva e bela", se fizermos nossas as palavras dele sobre a exposição Jorge de Castro, em 193921. Curiosamente, essa foto recupera um varal rabiscado em 1923 (Figura 5), pelo leitor da L'Esprit Nouveau, na folha de guarda do seu exemplar do n. 10, de outubro de $1921^{22}$.

A Codaque que busca, na paisagem amazônica, espelhos d'água e reflexos, recorre também à captação da sombra, o duplo ou uma espécie de alma da imagem, no auto-retrato. Do toldo do vaticano, em julho de 1927, Mário de Andrade/Turista Aprendiz surpreende a própria sombra e o ato de fotografar nas águas do Rio Madeira e se/nos pergunta, como no brinquedo do esconde-esconde: "Que-dê o poeta?" E que-dê o fotógrafo? perguntamos. Eles se juntam, por obra e graça do viajante, nas duas artes que ali recorrem à sombra projetada, contemplação de Narciso moderna, plena de humor e metáfora da criação. A figura de ponta-cabeça, além de aludir à técnica fotográfica, é o reflexo que, ao duplicar, deforma a imagem e estabelece, na inserção nas águas, uma nova realidade, a realidade da arte (Figura 6).

Assim, esse auto-retrato liga-se intimamente à poesia marioandradina, fortemente marcada pelo reflexo na água de rios. Em 1922, em Paulicéia desvairada, nos versos 11 e 12 de "Tietê", as braçadas do imigrante italiano e novo bandeirante abarcam a cidade moderna e cosmopolita dos cartazes comerciais, espelhada no rio. Em Noturno de Belo Horizonte, escrito em 1924 e
21. ANDRADE, Mário de. "O homem que se achou", publicada no n. 150 , da $1^{\text {a }}$ quinzena, jan. 1940.In:ANDRADE, 1992, p. 80.

22. Diante da inexistência de datas na L'Esprit Nouveau, a pesquisa da doutoranda Lílian Escorel, voltada para a leitura de Mário de Andrade dessa revista, logrou estabelecê-las. 


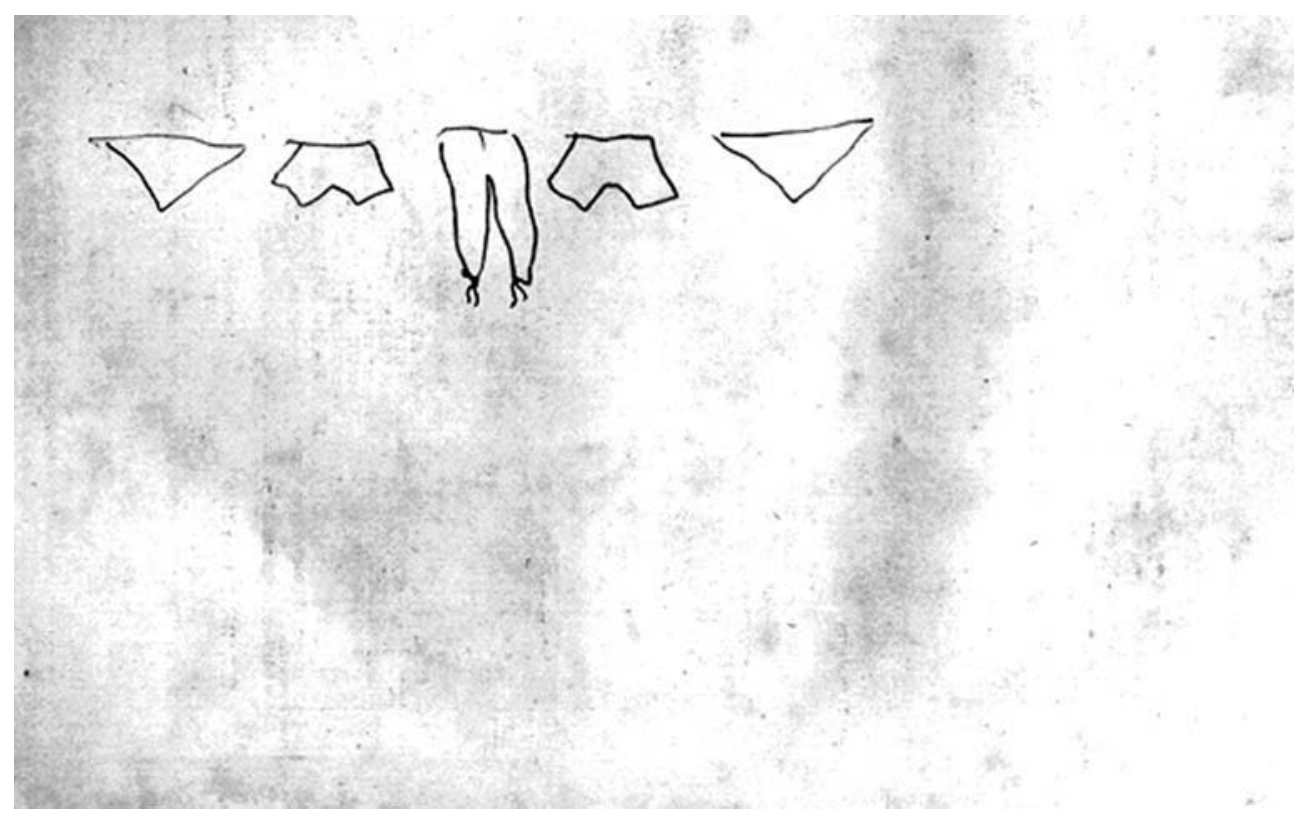

Figura 5 - Um varal rabiscado em 1923, pelo leitor da L'Esprit Nouveau, na folha de guarda do seu exemplar do n. 10, de outubro de 1921. Acervo do Instituto de Estudos Brasileiros da Universidade de São Paulo.

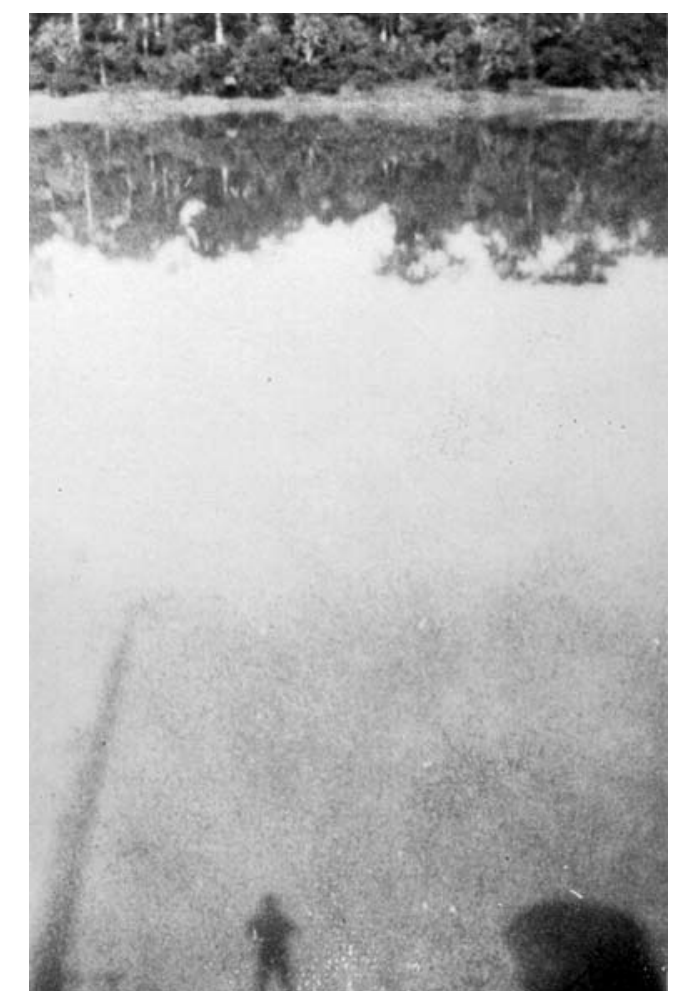

Figura 6 - Rio Madeira. Fotografia de Mário de Andrade. Acervo do Instituto de Estudos Brasileiros da Universidade de São Paulo. 
publicado em 1927, nas "lagoas polidas de cabeça para baixo" (v. 146), o poeta não avista apenas o tumulto e a calma da paisagem mineira, mas ele mesmo, metaforicamente, conforme a bela análise de Gilda de Mello e Souza ${ }^{23}$. E o eu lírico pontifica soberano sua condição de paulista, brasileiro e principalmente de homem, na Meditação sobre o Tietê, último poema da vida, em 1945. No rio, o eu lírico, incorporado ao caudal, "lágrima" e "alga", revisita, na cidade refletida, os temas e todos os caminhos do poeta. Pode-se presumir que, nesse auto-retrato de 1927 (Figura 7), estão as sementes de versos capitais para a definição do vate brasileiro, superada a contingência modernista: "Oh espelhos, ô Pirineus! Ô caiçaras!" (1 929), em "Eu sou trezentos...", e em "Brasão" - "Eu sou aquele que veio do imenso rio" (1937) -, que constam, respectivamente, de Remate de males e de "A costela do Grã Cão"24. Não é hora, porém, de analisar essa repercussão.

De volta a seu meio, em 1ำ de janeiro de 1928, na fazenda de Tarsila, no interior paulista, a objetiva funde Mário de Andrade ao solo, entregue a esse seu artefazer. No contorno de um gigante que ganha o título camoniano "Sombra minha", o gesto desvela a máquina-caixão. Renovadíssima forma do auto-retrato,
23.Ver "O colecionador e a coleção". In: BATISTA LIMA, 1984, p. XIII-XIX

24. O livro Remate de males, edição do autor de 1930, sai em São Paulo, onde a Livraria Martins Editora imprime, em 1941, Poesias, que inclui "A costela do Grã Cão".

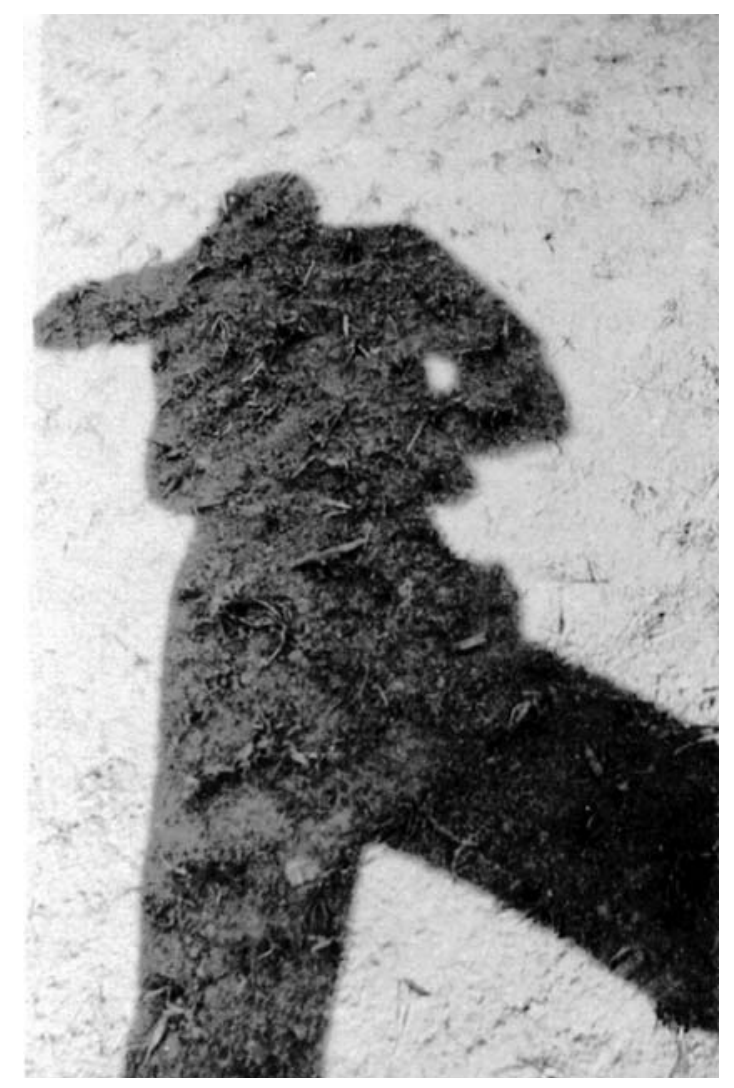

Figura 7 - Auto-retrato, 1927. Fotografia de Mário de Andrade. Acervo do Instituło de Estudos Brasileiros da Universidade de São Paulo. 
25."Catolé do Rocha", publicada na $1^{\text {a }}$ quinzena, maio 1939.In:ANDRADE, 1992. p. 38-33 será, no decênio de 1940, um dos trunfos de Ansel Adams, atualmente aplaudido em Friedlander.

A criação de Mário de Andrade fotógrafo, que tanto enriquece a produção do modernista da década de 1920, foi por ele divulgada uma única vez. A imagem de Catolé do Rocha, obtida em 1929, durante a viagem do Turista Aprendiz ao Nordeste, deu ensejo à crônica com o mesmo nome da cidadezinha paraibana, no Suplemento em Rotogravura do jornal $\bigcirc$ Estado de S.Paulo, em 1939 (Figura 8). No texto, uma espécie de movimento de câmera cinematográfica decodifica, para o leitor, as cores plasmadas na fotografia:

Era um domingo e na igrejinha branca, admirável pela harmonia da sua fachada sem torres, a procissão entrava. $\bigcirc$ céu estava negro de nuvens que não se resolviam a chover sobre a terra, e apenas do lado do poente, uma nesga de céu limpo deixava uns últimos raios do sol focalizarem, para efeitos da fotografia que encima estas evocações, a igreja e as casas da sua direita, no imenso largo vazio. No alto do morro, uma capelinha votiva também gritava muito espevitadamente o seu branco sem poeira, como um defeito de película fotográfica. E as casas coloridas, encarnadas, azuis, verde, limão, brincavam, numa esperança de alegria, com o ambiente feroz ${ }^{25}$.

Em 1929, no término do primeiro tempo modernista dos grupos, dos programas e das polêmicas, o empenho do fotógrafo arrefece até cessar sem explicações. Mais tarde, como diretor do Departamento de Cultura da

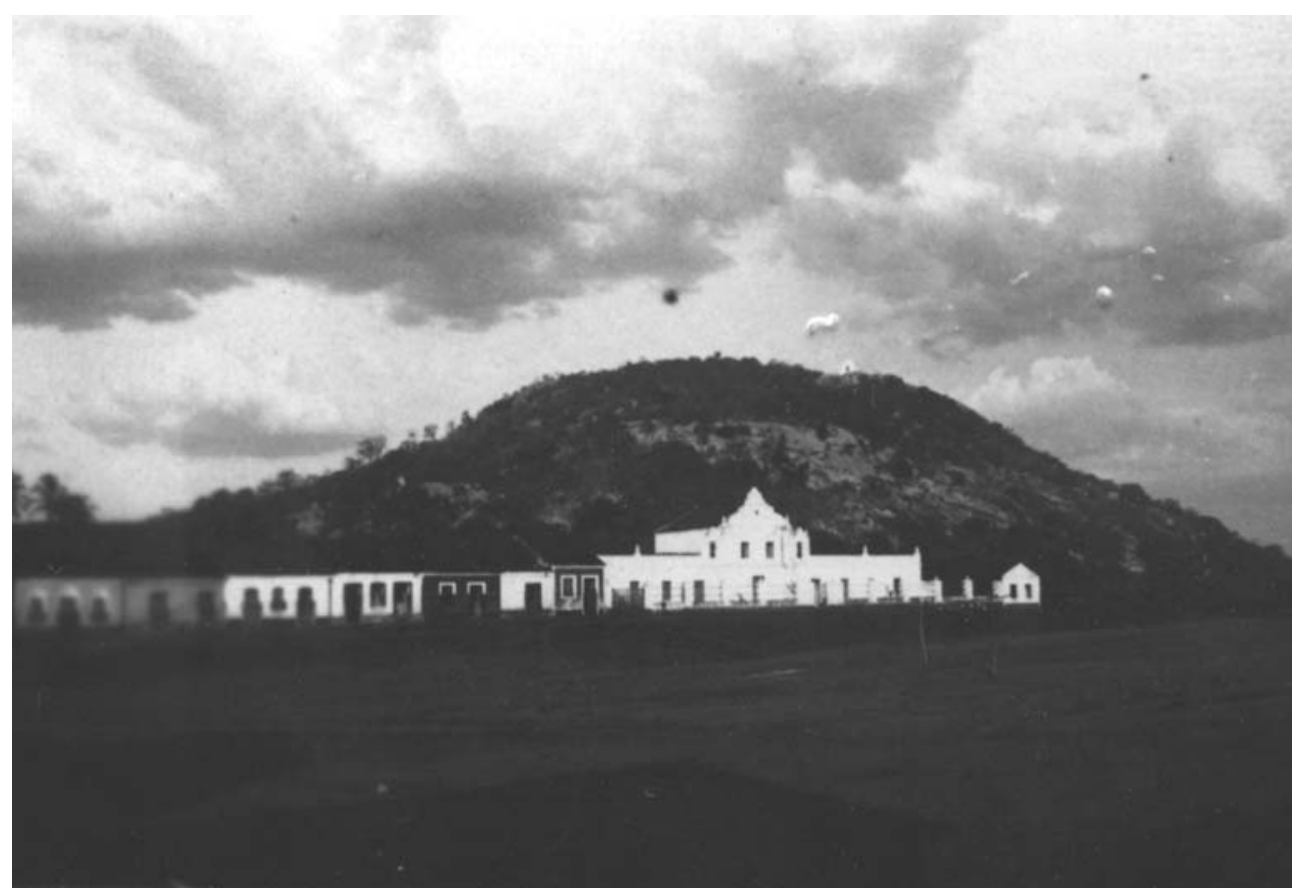

Figura 8 - Catolé do Rocha, 1929. Fotografia de Mário de Andrade. Acervo do Instituto de Estudos Brasileiros da Universidade de São Paulo. 
Municipalidade de São Paulo ou como delegado do Serviço do Patrimônio Histórico e Artístico Nacional, Mário de Andrade incentivará a fotografia ao contratar dois excelentes profissionais, Benedito Duarte e Germano Graeser. Como cronista e crítico do suplemento Rotogravura, em 1939 focalizará as fotomontagens do poeta Jorge de $\operatorname{Lima}^{26}$ e, em 1940, a exposição de Jorge de Castro. Escreve então:

[...] aquilo em que a fotografia artística se eleva sobre a puramente documental, reside não na máquina ou na luz, como imaginam confusionistamente os manipuladores de truques fotográficos ou os fotografadores de eternos crepúsculos românticos, mas na criação humana do artista. Enfim, há que ter esse dom especial de apanhar "a poesia do real", como disse muito bem o desenhista Santa Rosa, justamente a propósito das fotografias do sr. Jorge de Castro $^{27}$.
26."Fantasias de um poeta", publicada no n. 146; $1^{\mathrm{a}}$ quinzena, nov. 1939.In: Id., p. 71.

27. "O homem que se achou". In: Ibid, p. 80

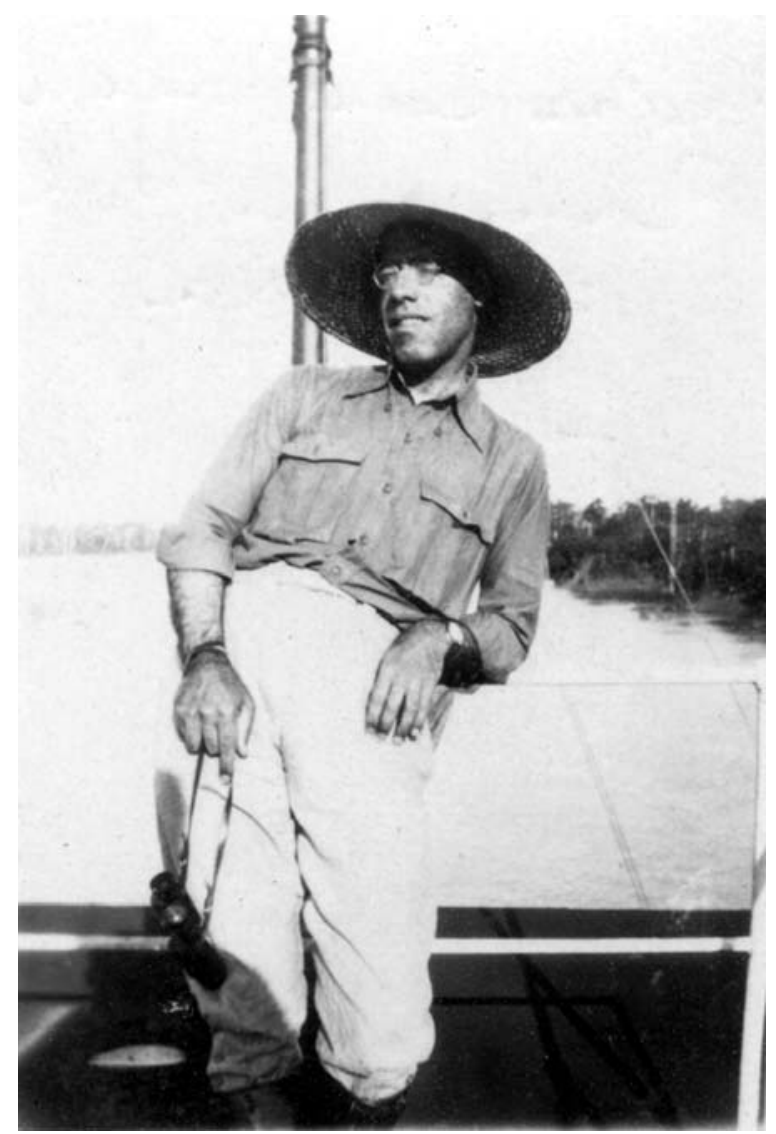

Figura 9 - "A bordo do S. Salvador em pleno Peru com Sol na cara/ 22-Vl-27" (notação no verso). Acervo do Instituto de Estudos Brasileiros da Universidade de São Paulo. 


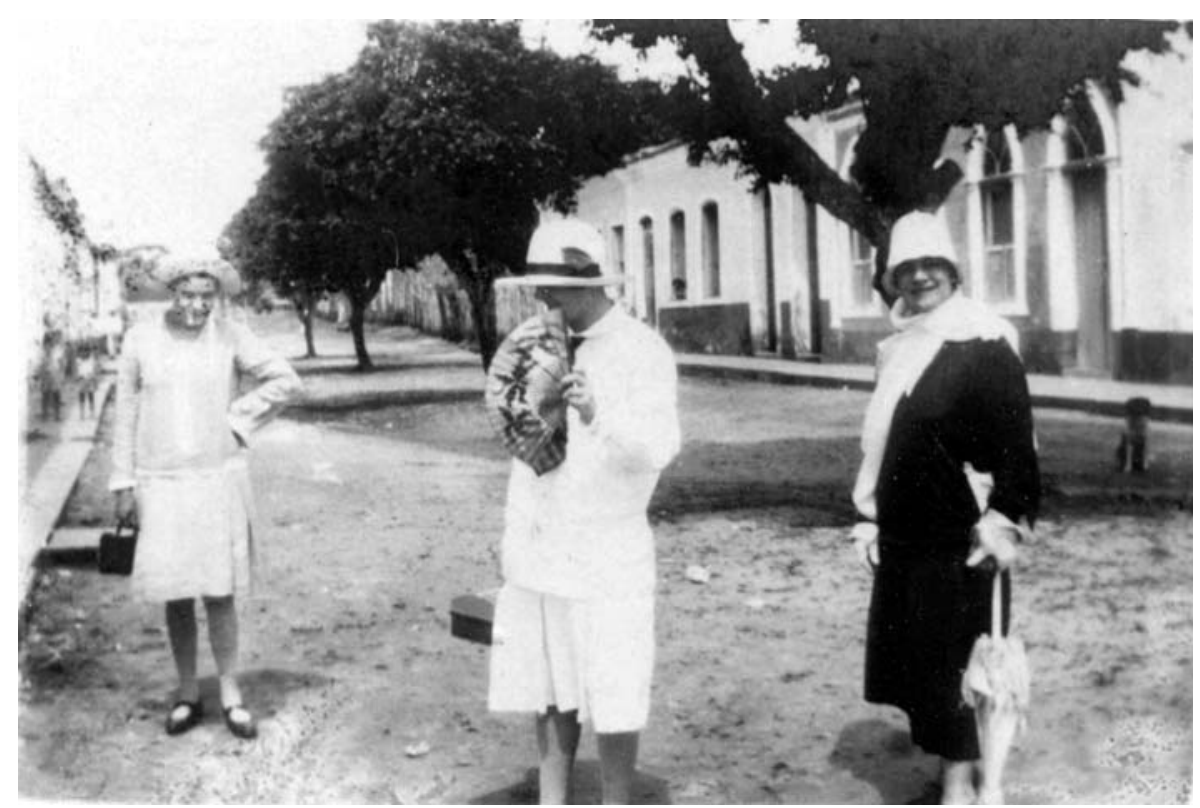

Figura 10 - "Coari - 1 1-VI-27/ Alto Solimões/ Manacá Trombeta e Balança" Inotação no verso). Acervo do Instituto de Estudos Brasileiros da Universidade de São Paulo.

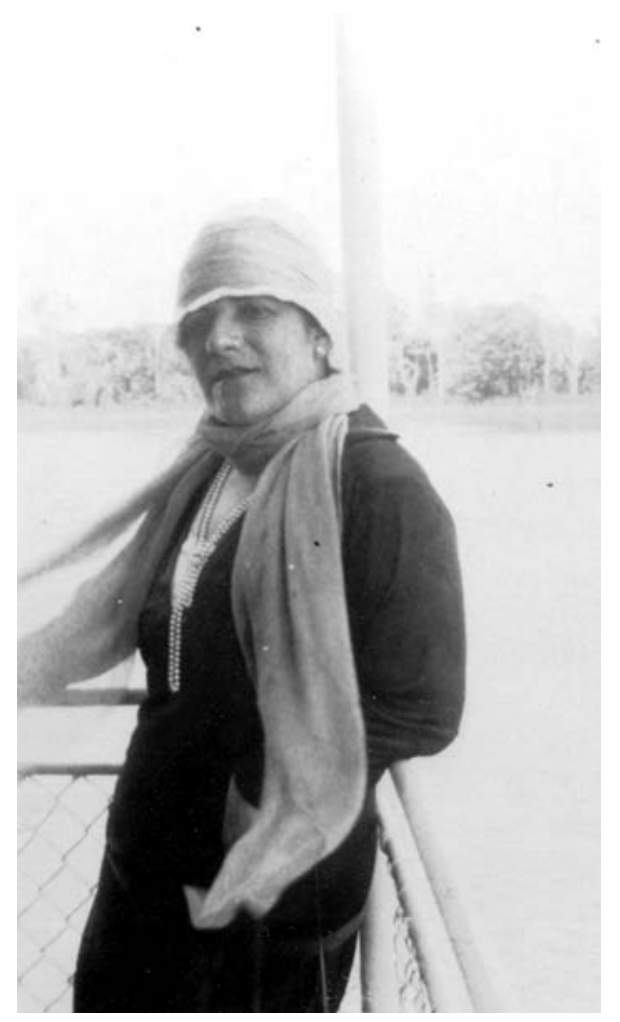

Figura 11 - "Nossa Senhora no Madeira/ 4-Julho-1927" (notação no verso). Acervo do Instituto de Estudos Brasileiros da Universidade de São Paulo. 


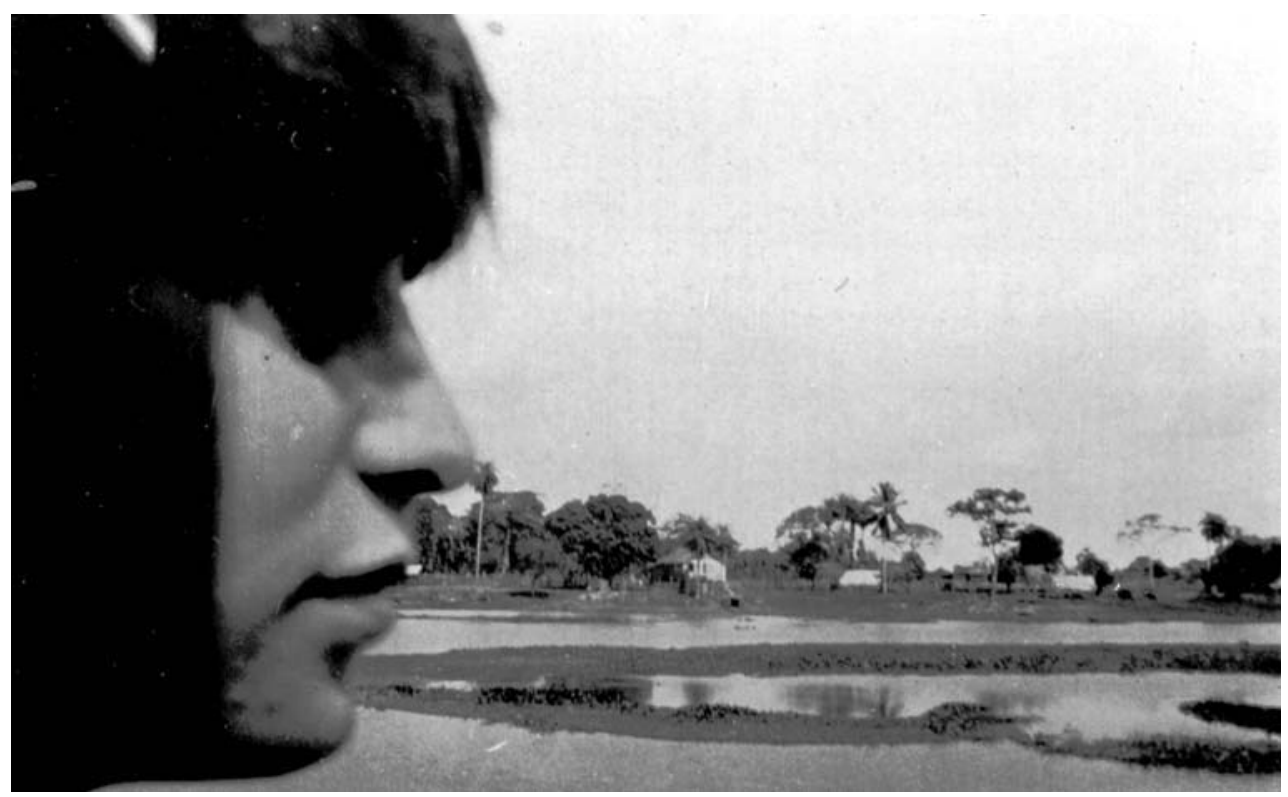

Figura 12 - "Dolur na vista marajoara 3 1-VII-27/ Sol 3 diaf. 3/ Trombeta" (notação no verso). Acervo do Instituto de Estudos Brasileiros da Universidade de São Paulo.

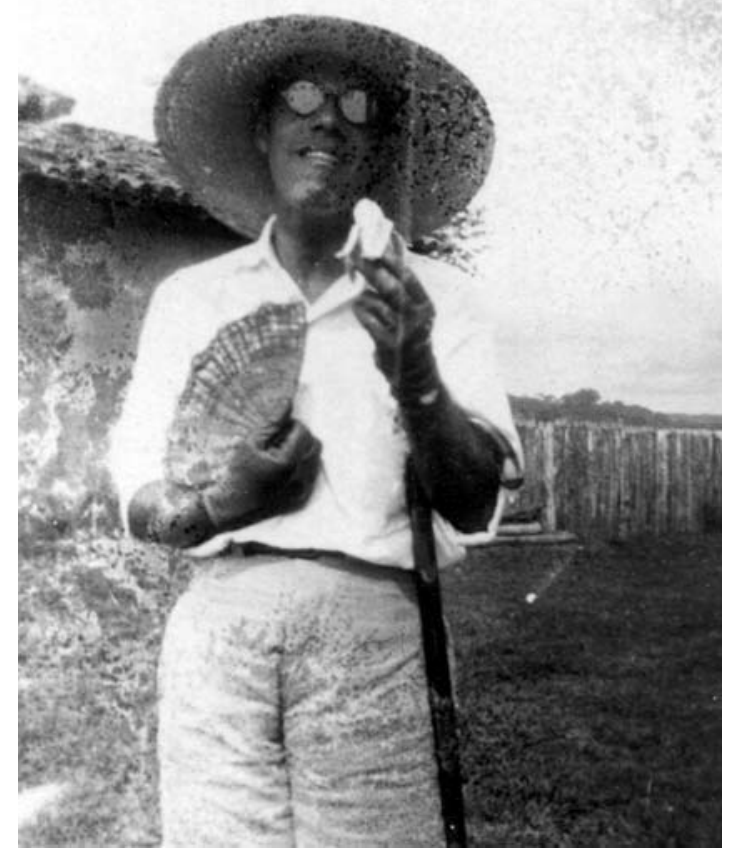

Figura 13 - "Aposta de Ridículo em Tefé/ 12-VI-27" (notação no verso). Acervo do Instituto de Estudos Brasileiros da Universidade de São Paulo. 


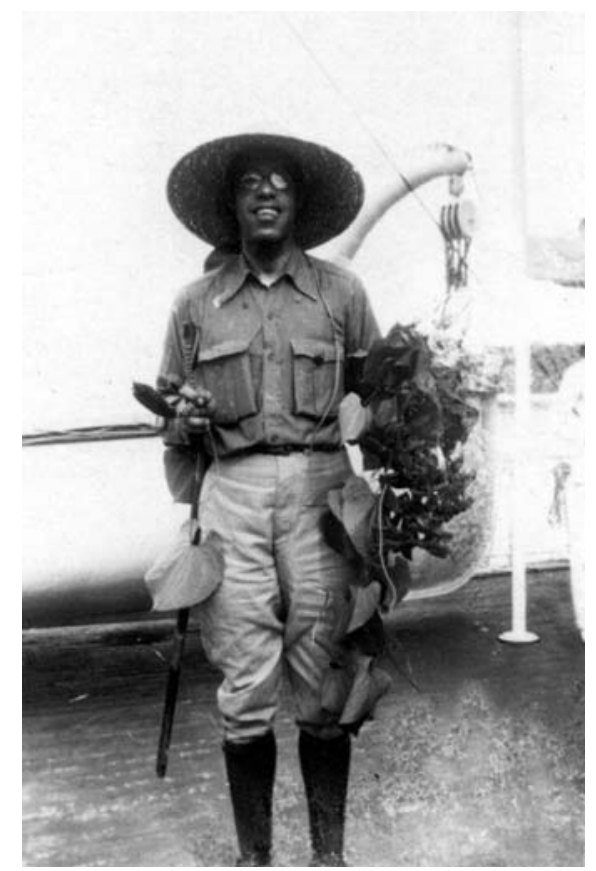

Figura 14 - "Assacaio/ (na mão direita uma flor feito cachimbo. Um grupo de flores bicos-deararas na outra/ 17-VI-27" (notação no verso). Acervo do Instituto de Estudos Brasileiros da Universidade de São Paulo.

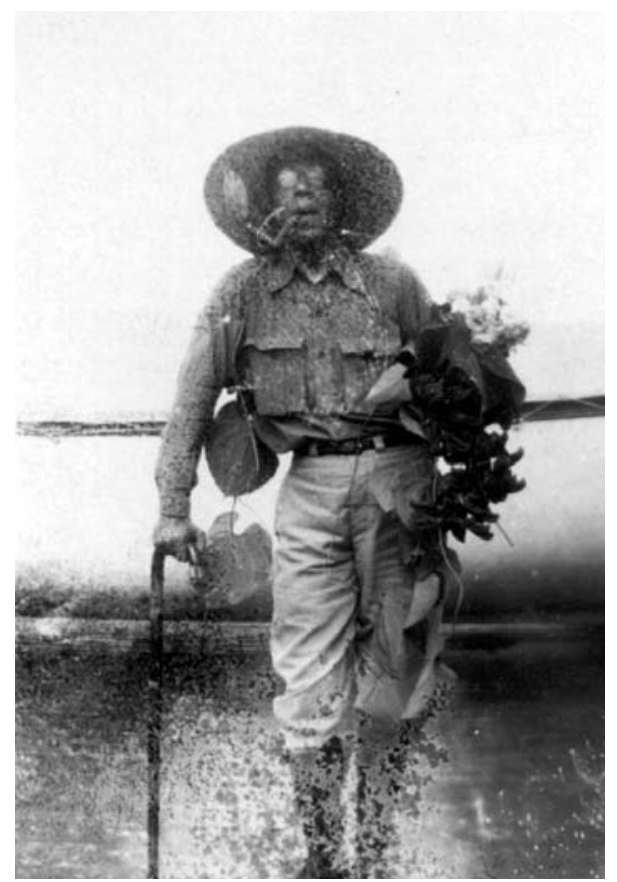

Figura 15 - "Eu voltando do passeio por Assacaio/ 17-Vl-27/ Monstro à mostra" (notação no verso). Acervo do Instituto de Estudos Brasileiros da Universidade de São Paulo. 


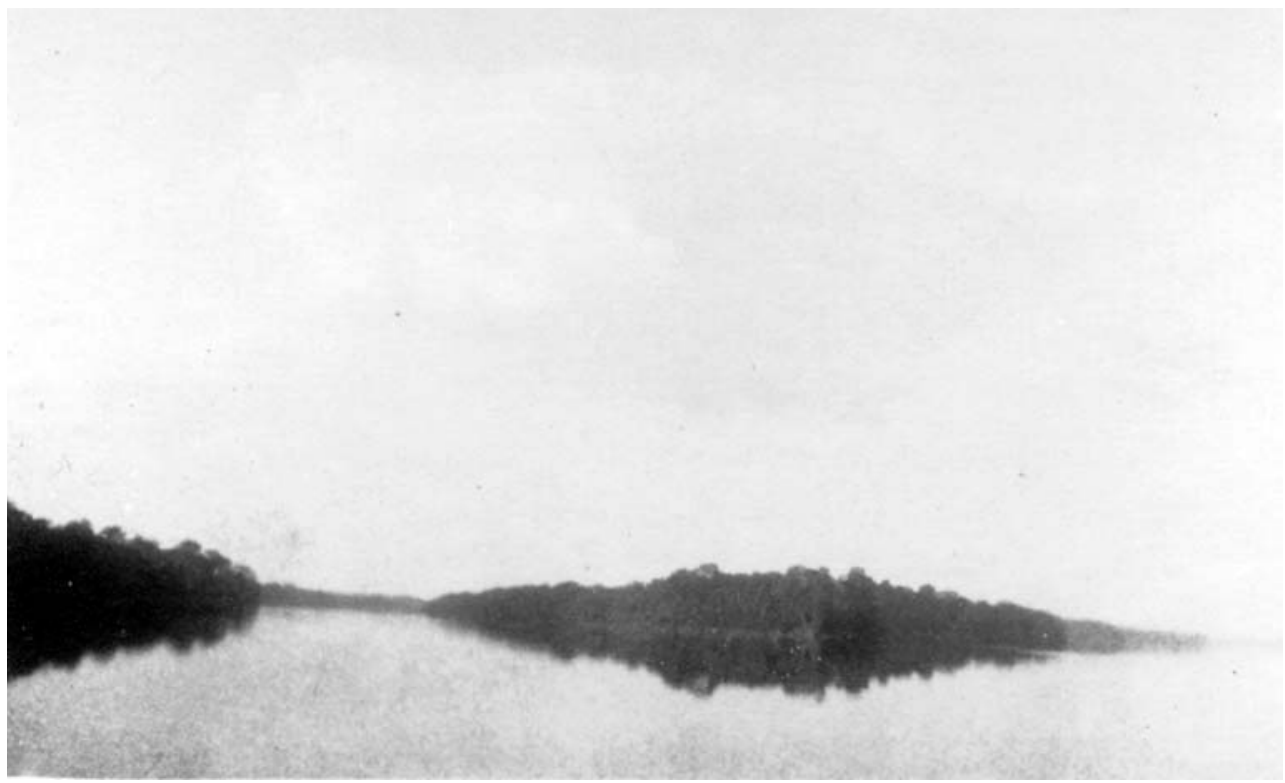

Figura 16 - "Entrada dum paraná ou paranã/ rio Madeira/ 5-VII-27/ Iha de Manicoré. O I é o rio Mataurá, o ll é o Madeira" (notação no verso). Acervo do Instituto de Estudos Brasileiros da Universidade de São Paulo.

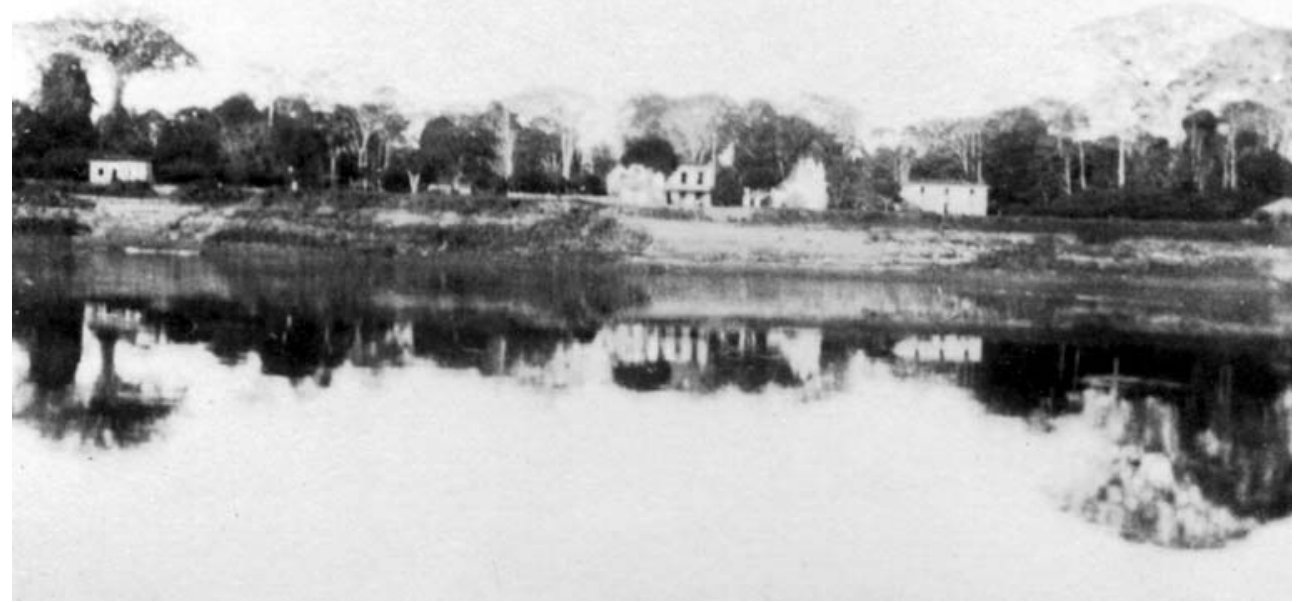

Figura 17 - "Bom-Futuro bonita/ O II é um igrejó gótico/ 6-VII-27/ rio Madeira/Ver as sumanúmas dos dois lados/ água de Narciso" (notação no verso). Acervo do Instituto de Estudos Brasileiros da Universidade de São Paulo. 


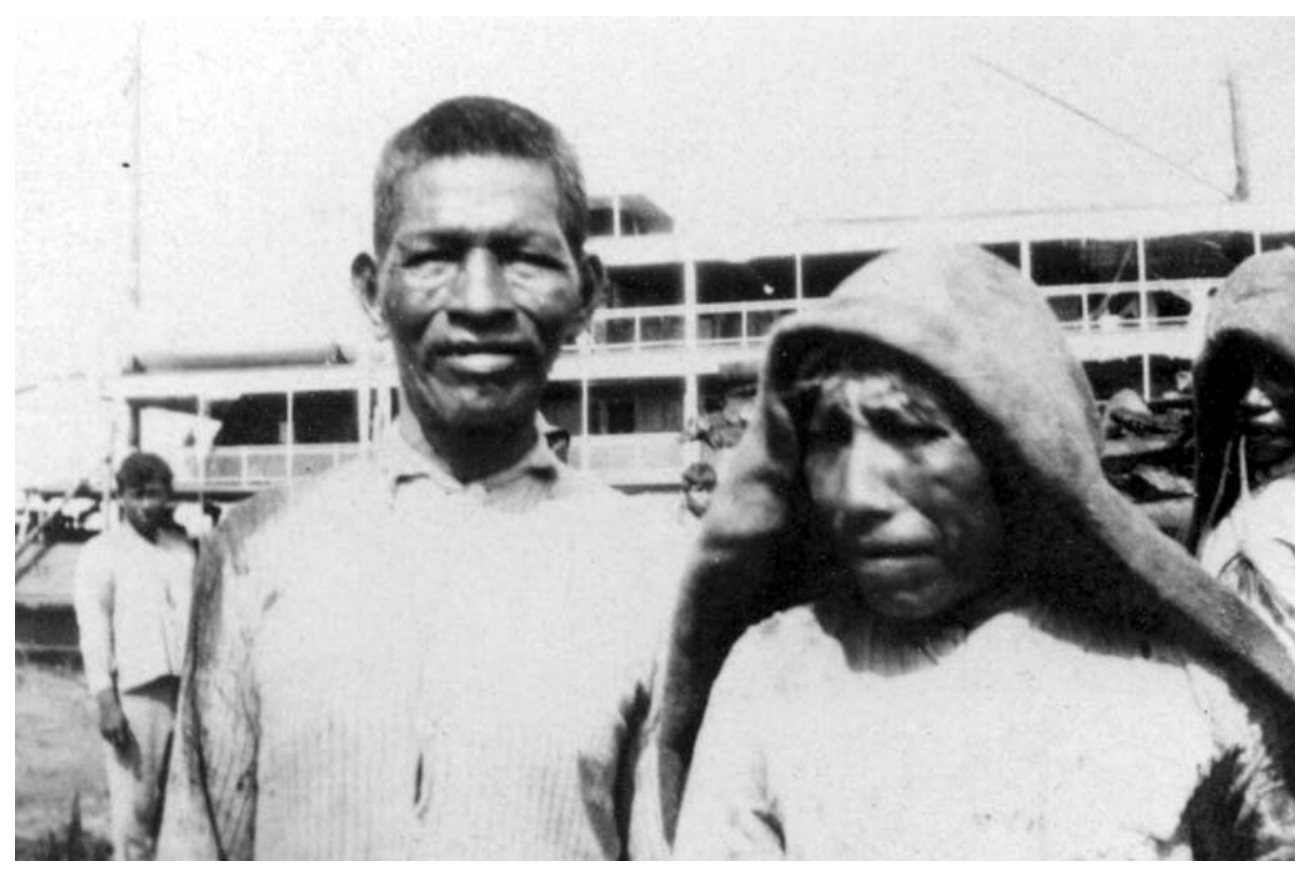

Figura 18 - "Assacaio/ 17-VI-27/ O mais alto é enegrecido pintado de genipapo" (notação no verso). Acervo do Instituto de Estudos Brasileiros da Universidade de São Paulo.

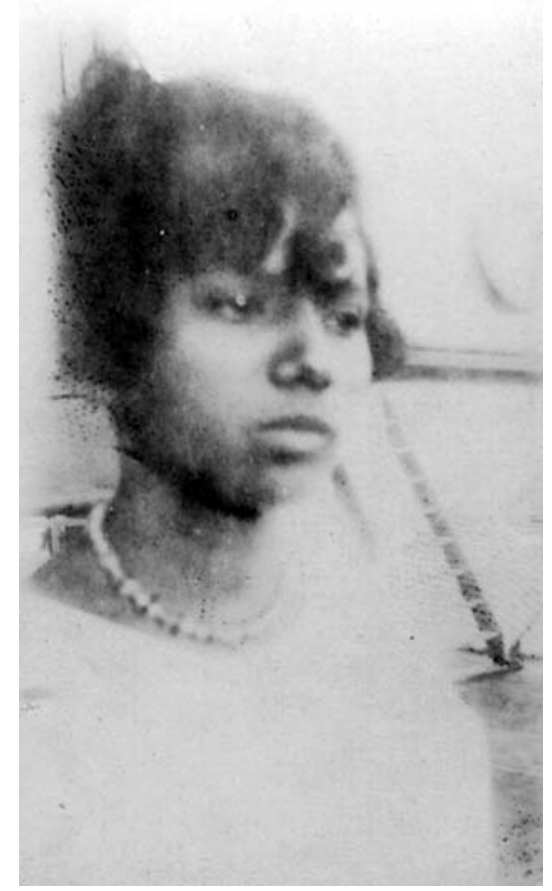

Figura 19 - "Boniteza tapuia/ De fato ela era mais bonita que o retrato. S. Salvador/ 1-VII-27/ 'A Venus do milho'!" (notação no verso). Acervo do Instituto de Estudos Brasileiros da Universidade de São Paulo. 


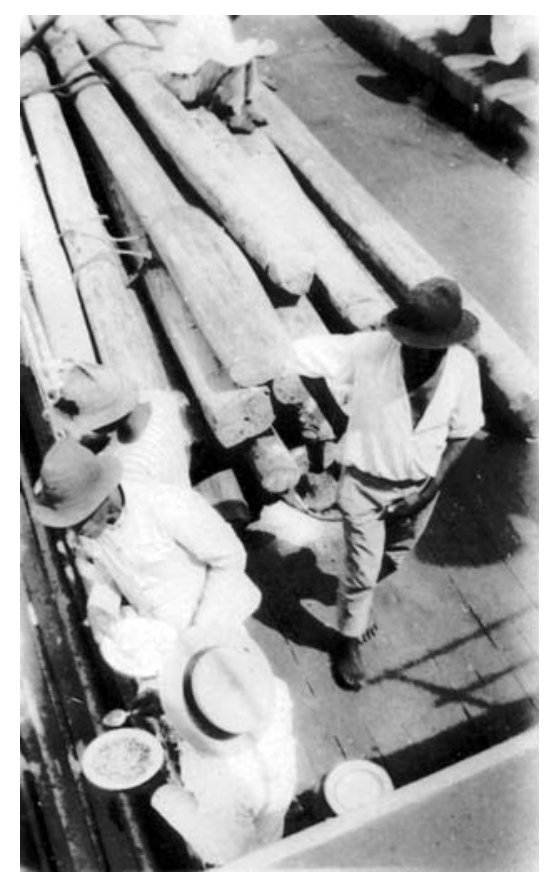

Figura 20 - "Almoço da 3․ Classe. Baependy - ao largo/ 6-VIII-27/ diaf. 1 - Sol 1 das 10 Em terceira voracidade" (notação no verso). Acervo do Instituto de Estudos Brasileiros da Universidade de São Paulo.

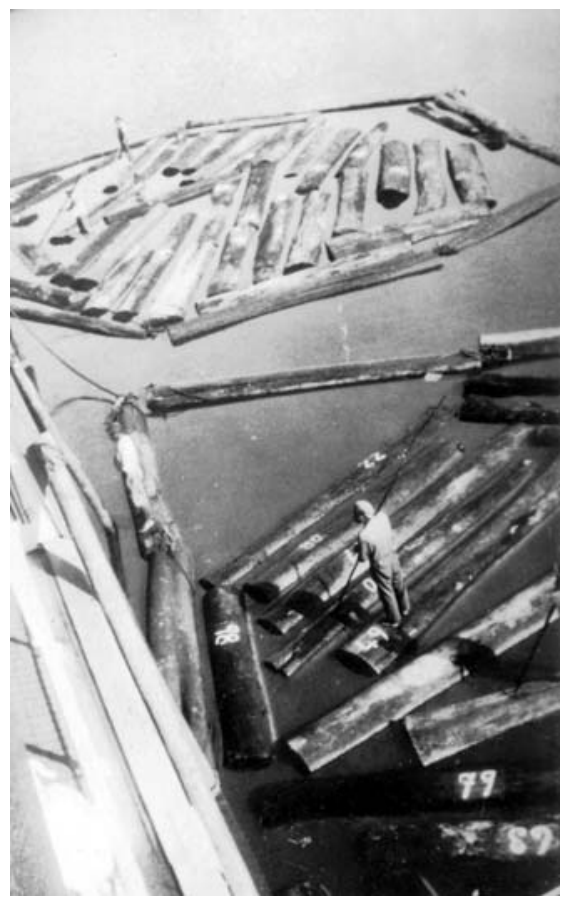

Figura 21 - "Jangadas de mogno enconstando no S. Salvador pra embarcar/Nanay 23- Junho 1927 / Peru/Vitrolas futuras" (notação no verso). Acervo do Instituto de Estudos Brasileiros da Universidade de São Paulo. 


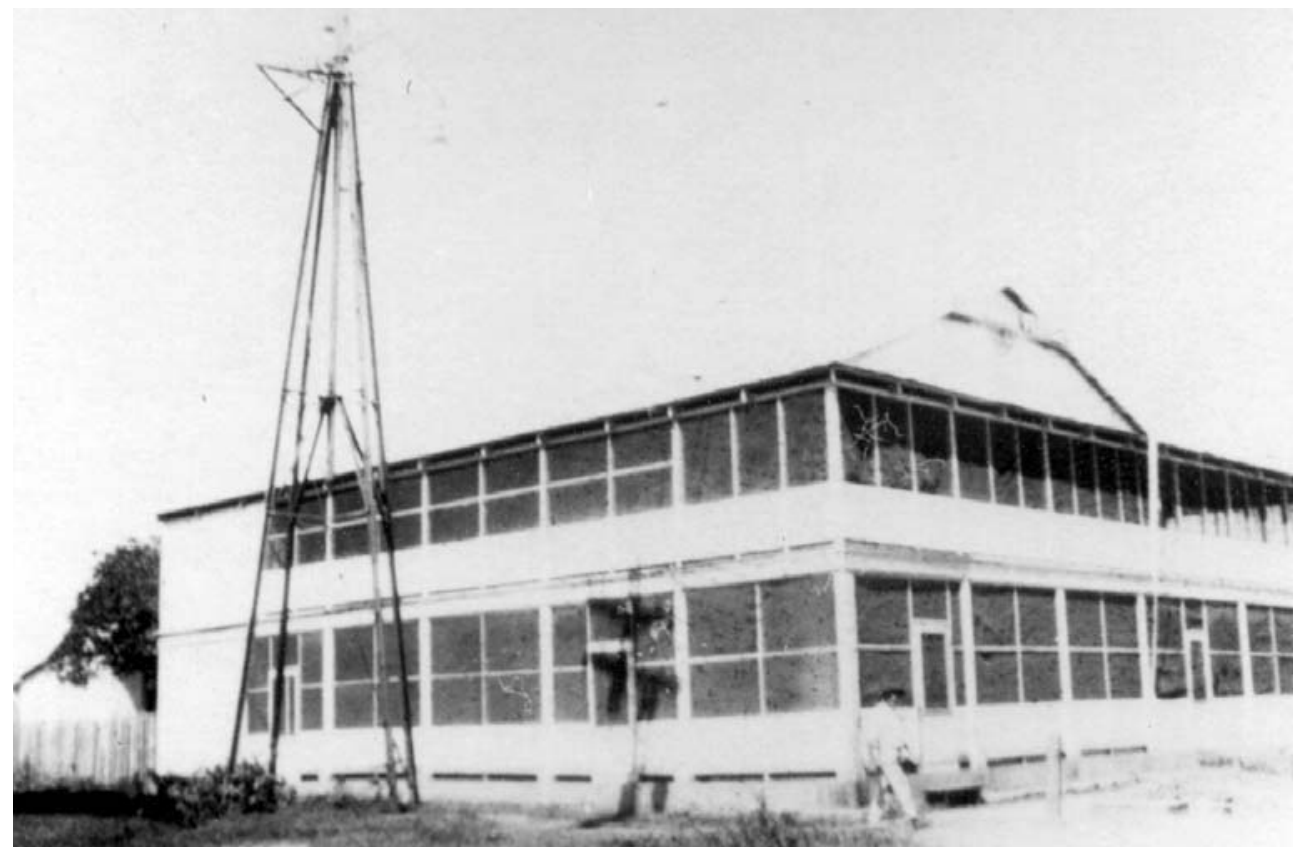

Figura 22 - "Casa telada da Madeira-Mamoré/ Porto Velho - 1 1-VI-27/ Obj. 2 Sol 1/ 13 e 10" (notação no verso). Acervo do Instituto de Estudos Brasileiros da Universidade de São Paulo.

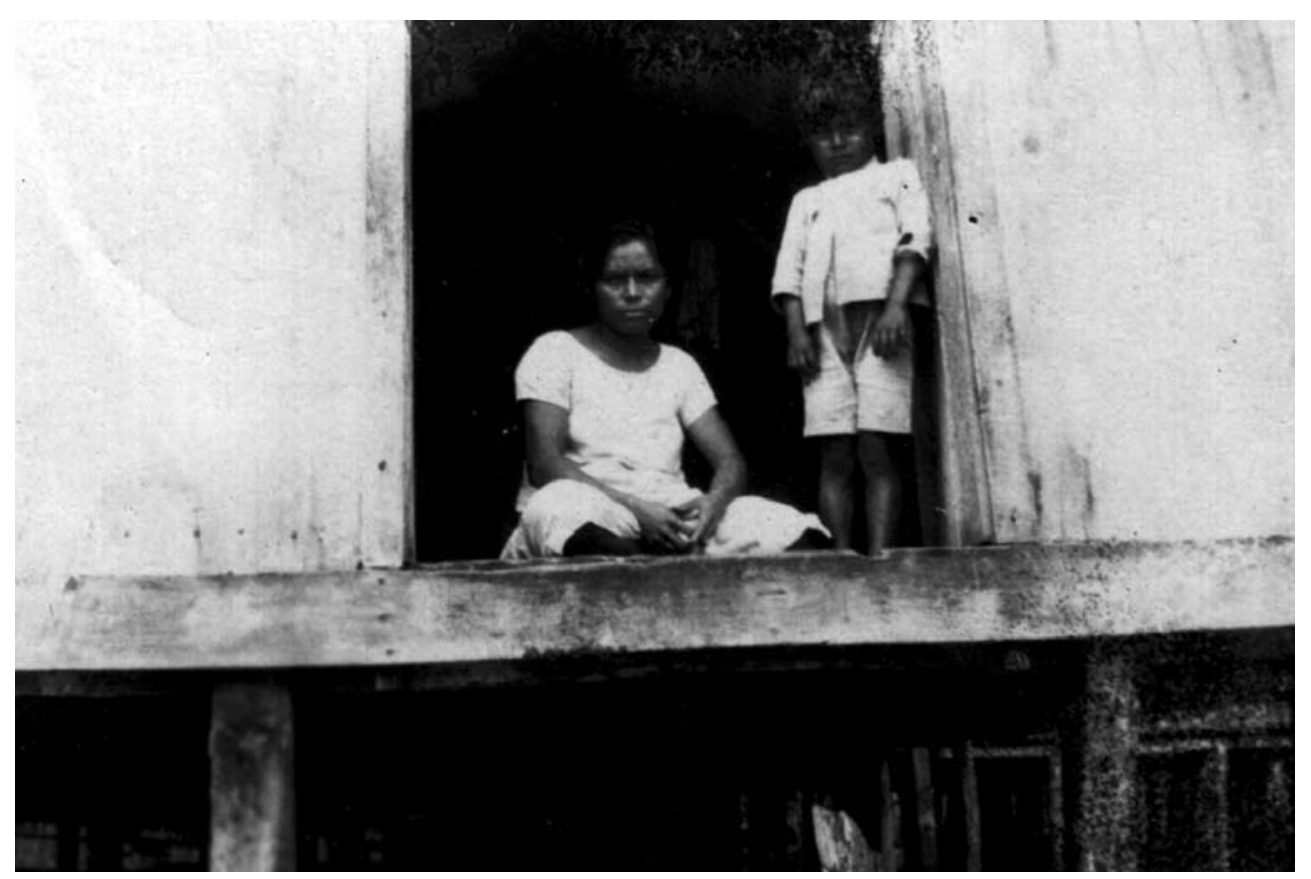

Figura 23 - "Margem do Solimões/ Junho - 1927/ Sobre as ondas" (notação no verso). Acervo do Instituto de Estudos Brasileiros da Universidade de São Paulo. 


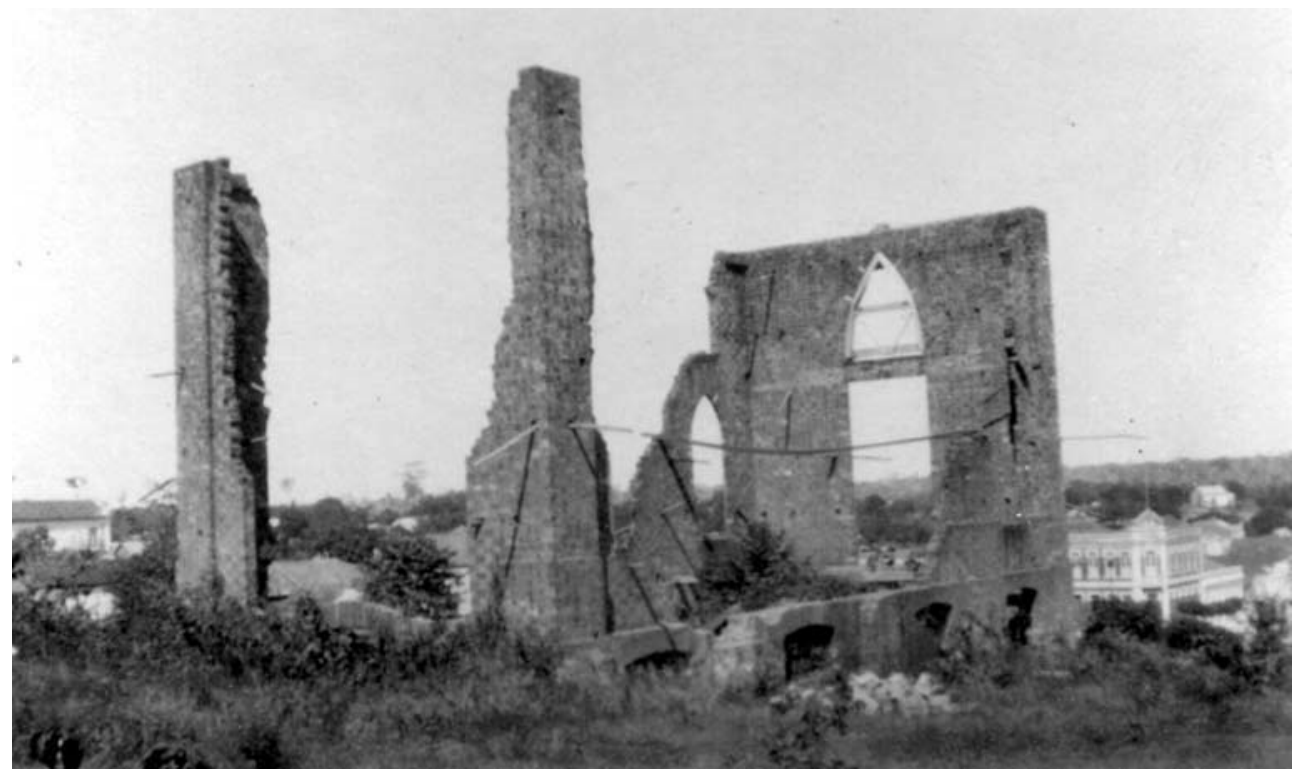

Figura 24 - "Única igreja de Porto-Velho/ 1 1-Vl-27/ Sol 1 Diaf. 213 e 15/Nun arm Ich bin gehst du zuruck" (notação no verso). Acervo do Instituto de Estudos Brasileiros da Universidade de São Paulo.

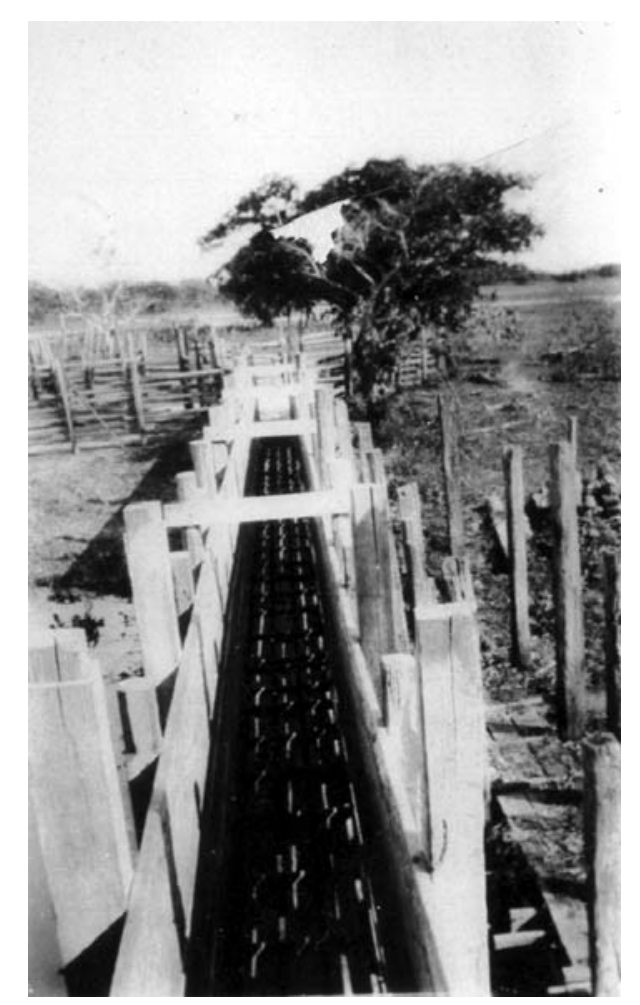

Figura 25 - "Caiçara pra embarque de gado/ S. Joaquim/ Maraió 29-VII-27/ diaf. 1, sol 1 das 16" (notação no verso). Acervo do Instituto de Estudos Brasileiros da Universidade de São Paulo. 


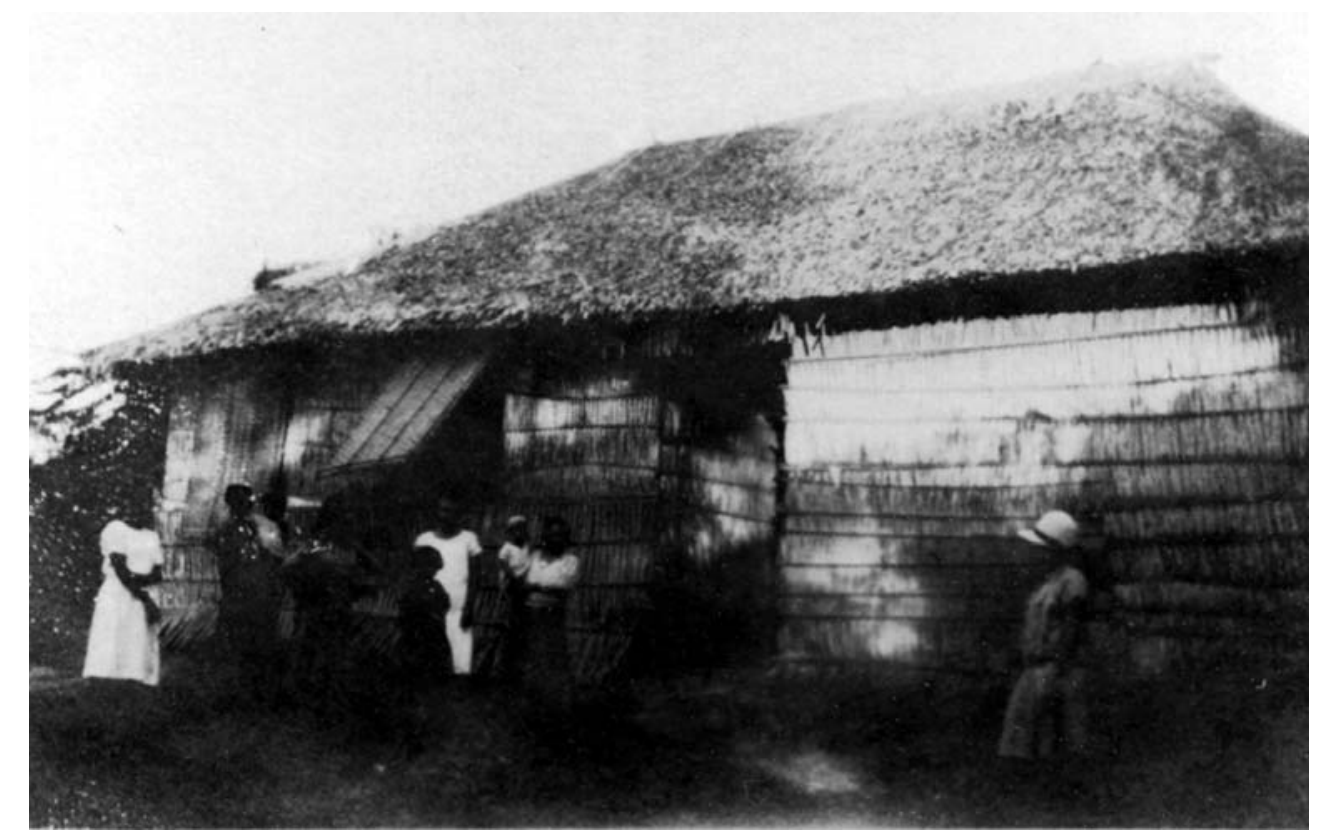

Figura 26 - "Caiçara/ rio Madeira/ 3-VII-27" (notação no verso). Acervo do Instituto de Estudos Brasileiros da Universidade de São Paulo.

\section{O CODAQUE E A EXPERIMENTAÇÃO ARTÍSTICA}

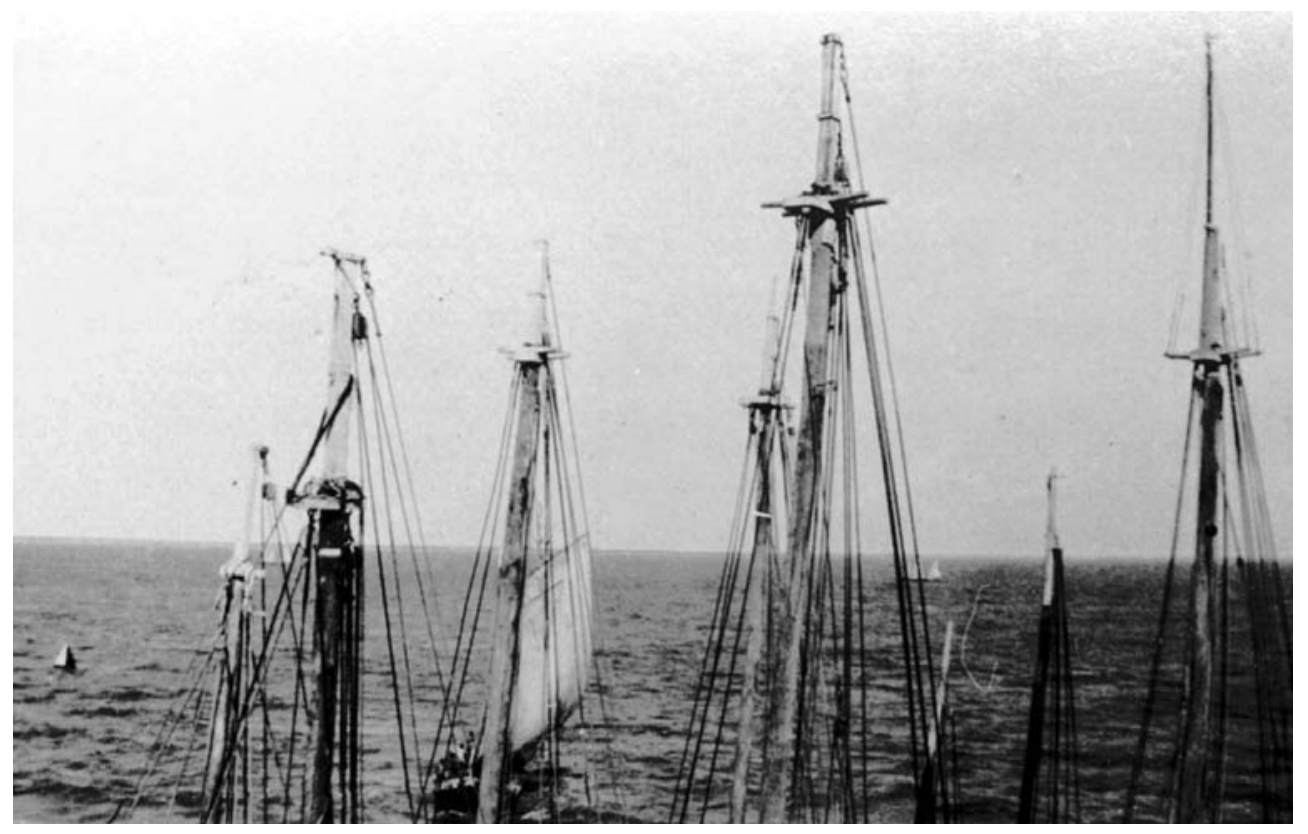

Figura 27 - "Veleiros encostados no Baependy/ Areia Branca/ 6-VIII-27/ Diaf. 3 - sol 1 das 7 e 40" (notação no verso). Acervo do Instituto de Estudos Brasileiros da Universidade de São Paulo. 


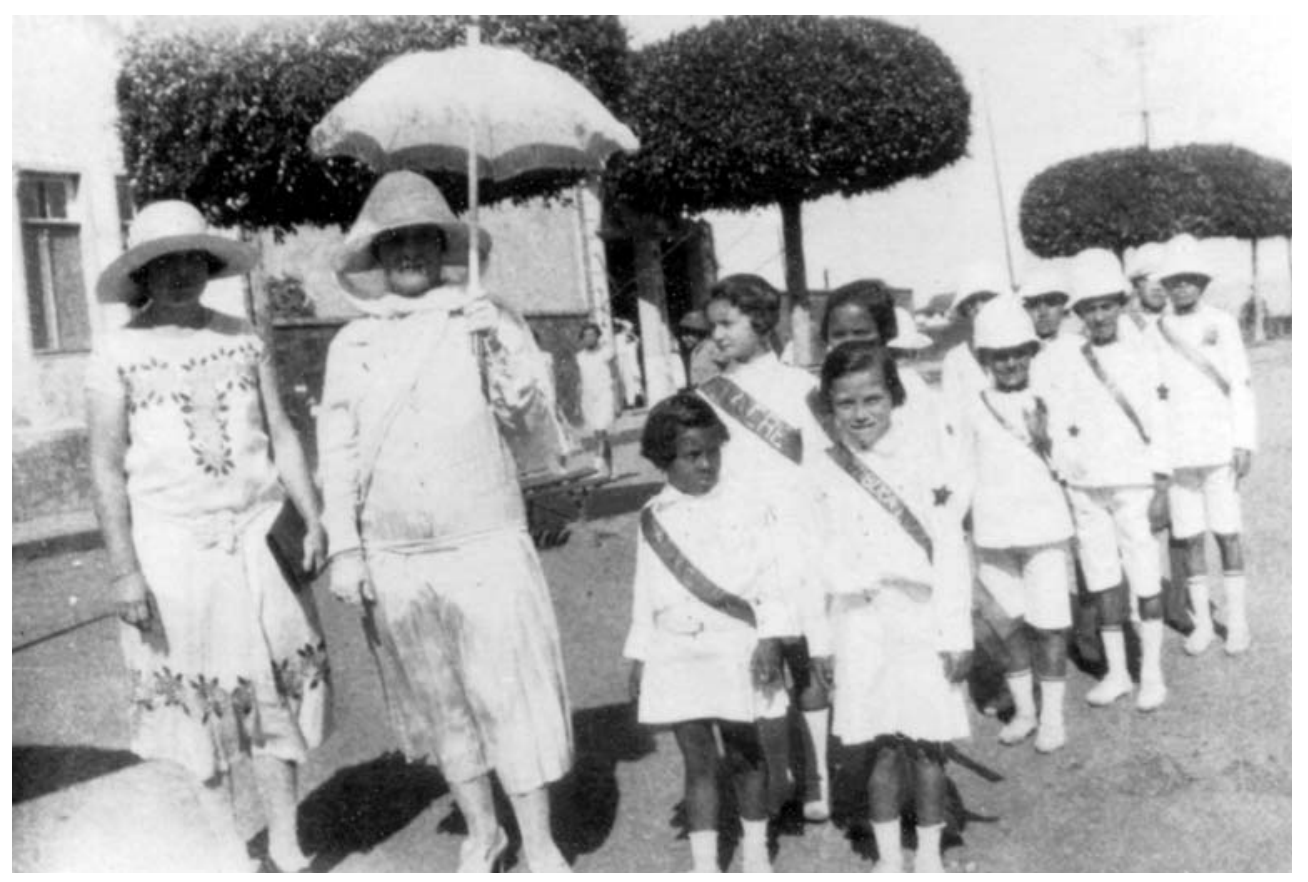

Figura 28 - "Procissão de Nossa Senhora em Porto-Velho/ 15-VII-27" (notação no verso). Acervo do Instituto de Estudos Brasileiros da Universidade de São Paulo.

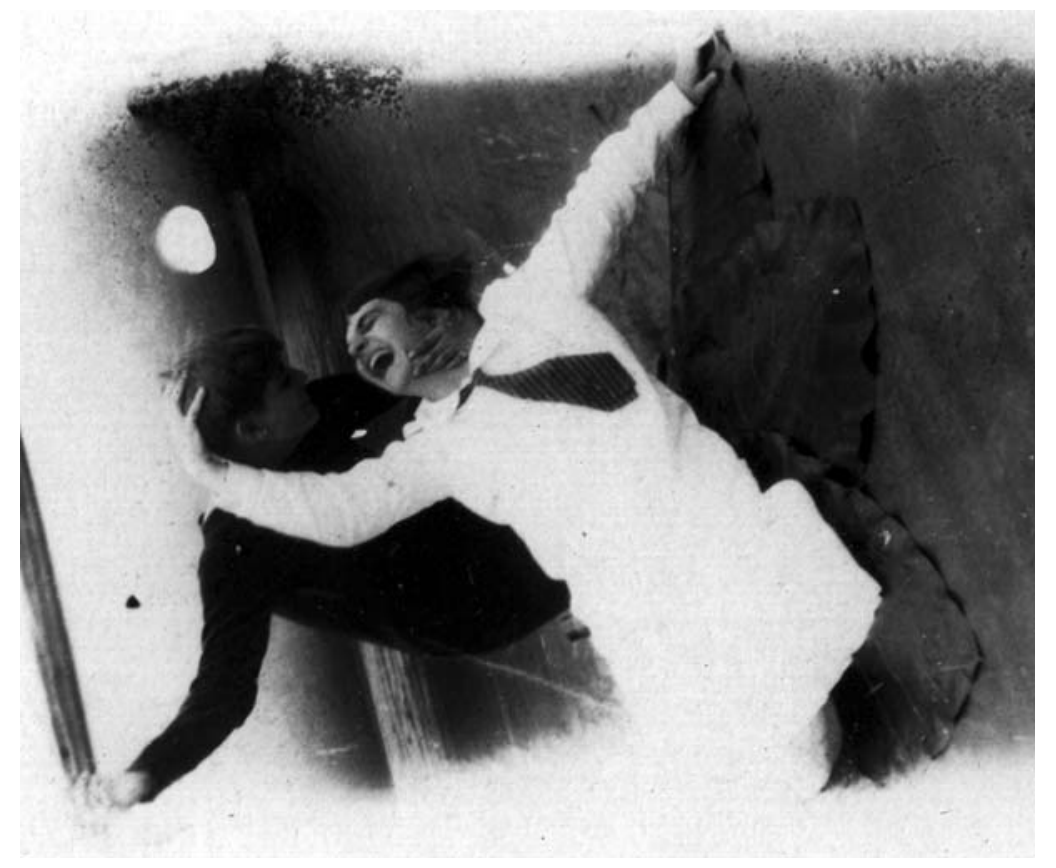

Figura 29 - "Amor e Psiquê no Solimões/ Junho - 1927/ Canova 1927" (notação no verso). Acervo do Instituto de Estudos Brasileiros da Universidade de São Paulo. 


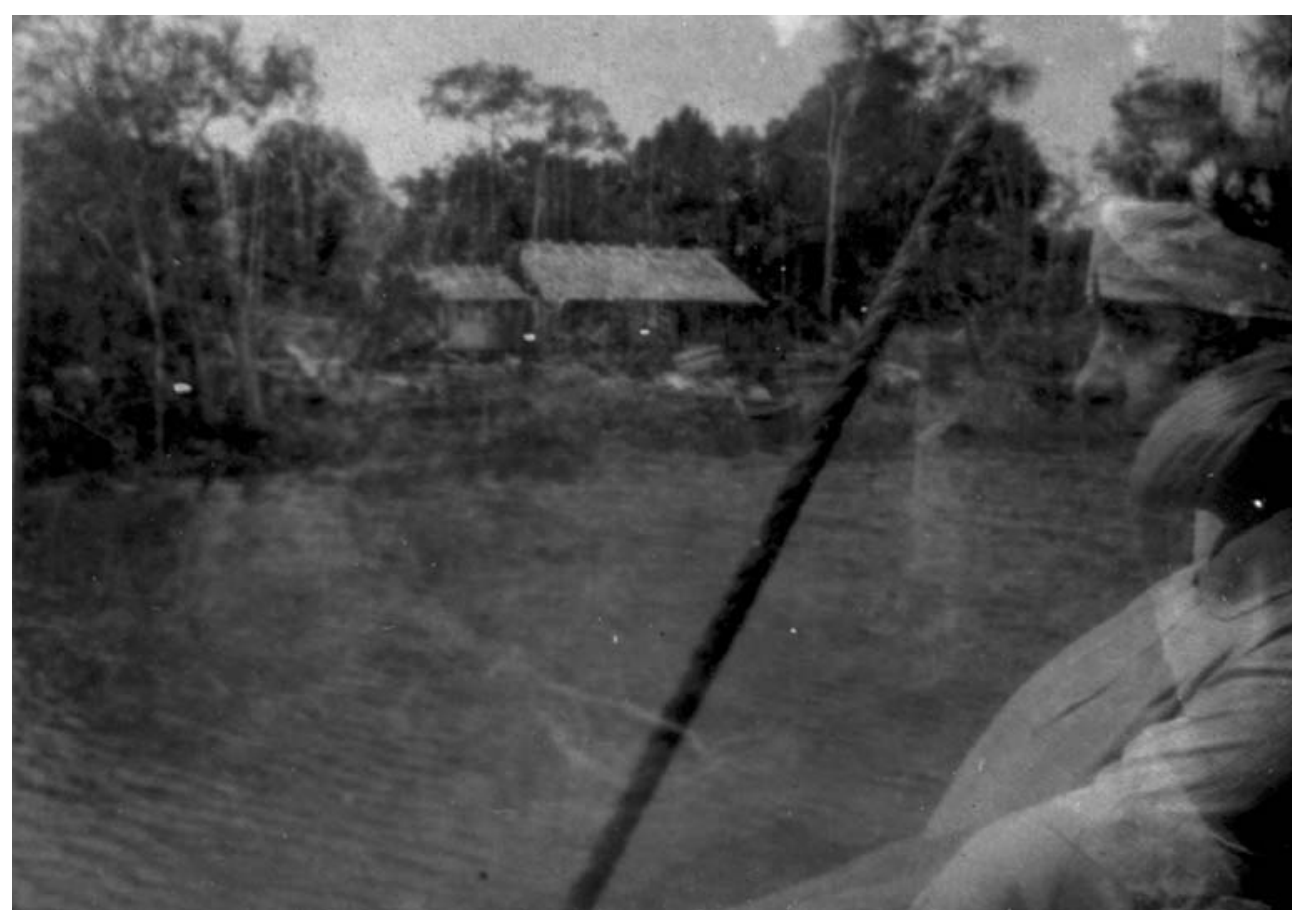

Figura 30 - "Foto futurista de Mag e Dolur sobrepostas às margens do Amazonas / Junho 1927 / Obsessão" (notação no verso). Acervo do Instituto de Estudos Brasileiros da Universidade de São Paulo.

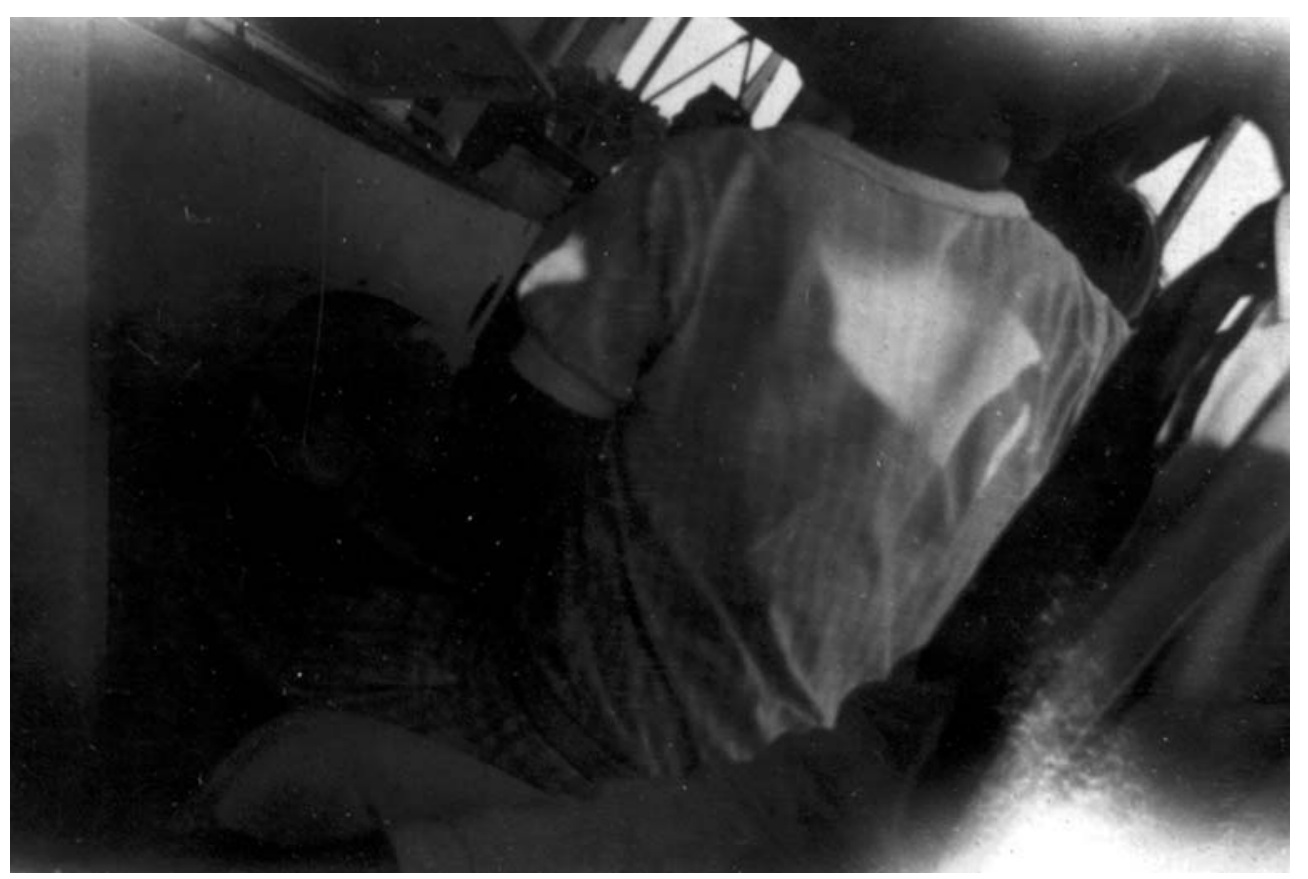

Figura 31 - "Desvairismo por acaso/ questão de lancha e de lunch/ 7-Vl-27" (notação no verso). Acervo do Instituto de Estudos Brasileiros da Universidade de São Paulo. 


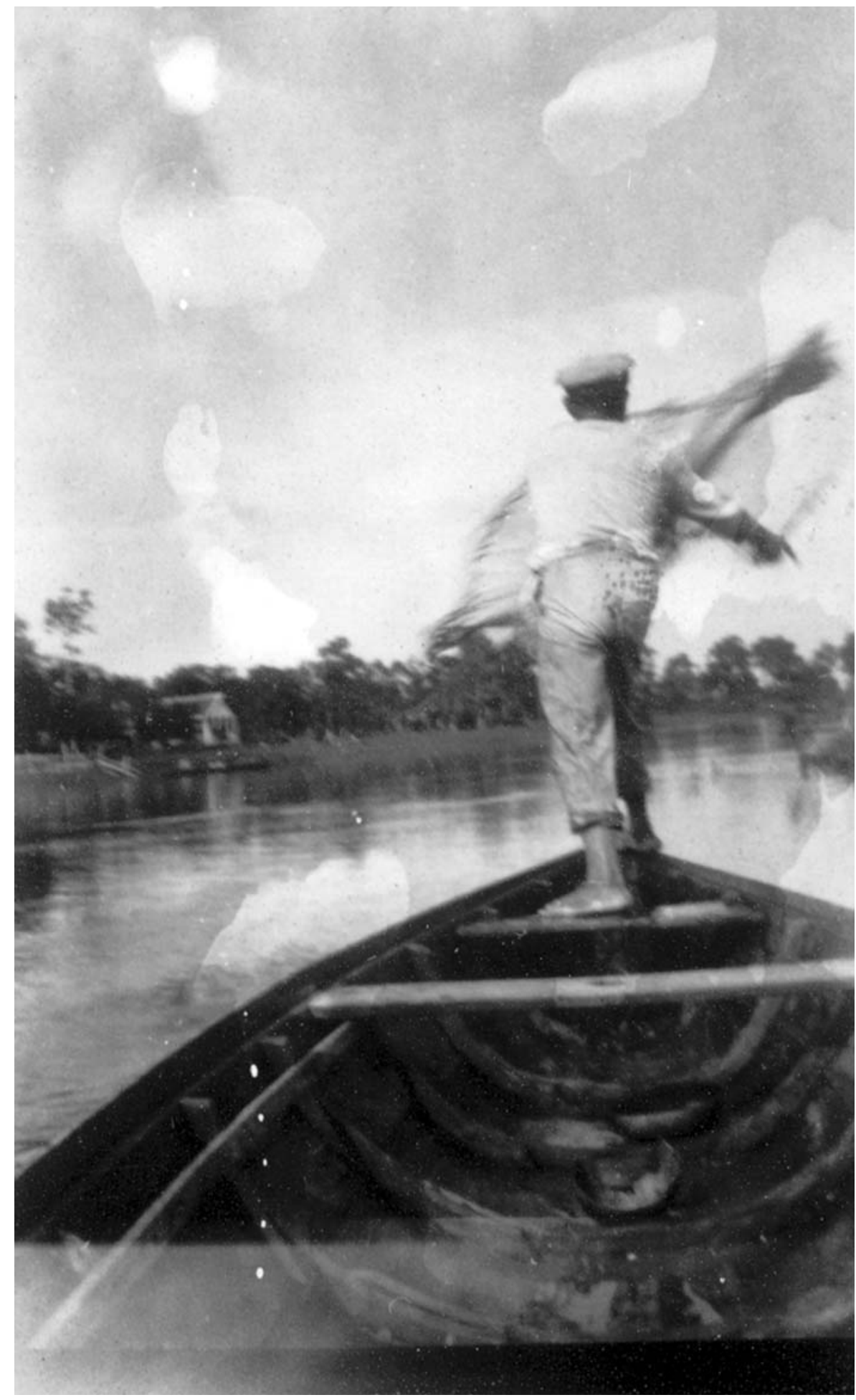

Figura 32 - "Futurismo pingando 7-VI-27" (notação no verso). Acervo do Instituto de Estudos Brasileiros da Universidade de São Paulo. 


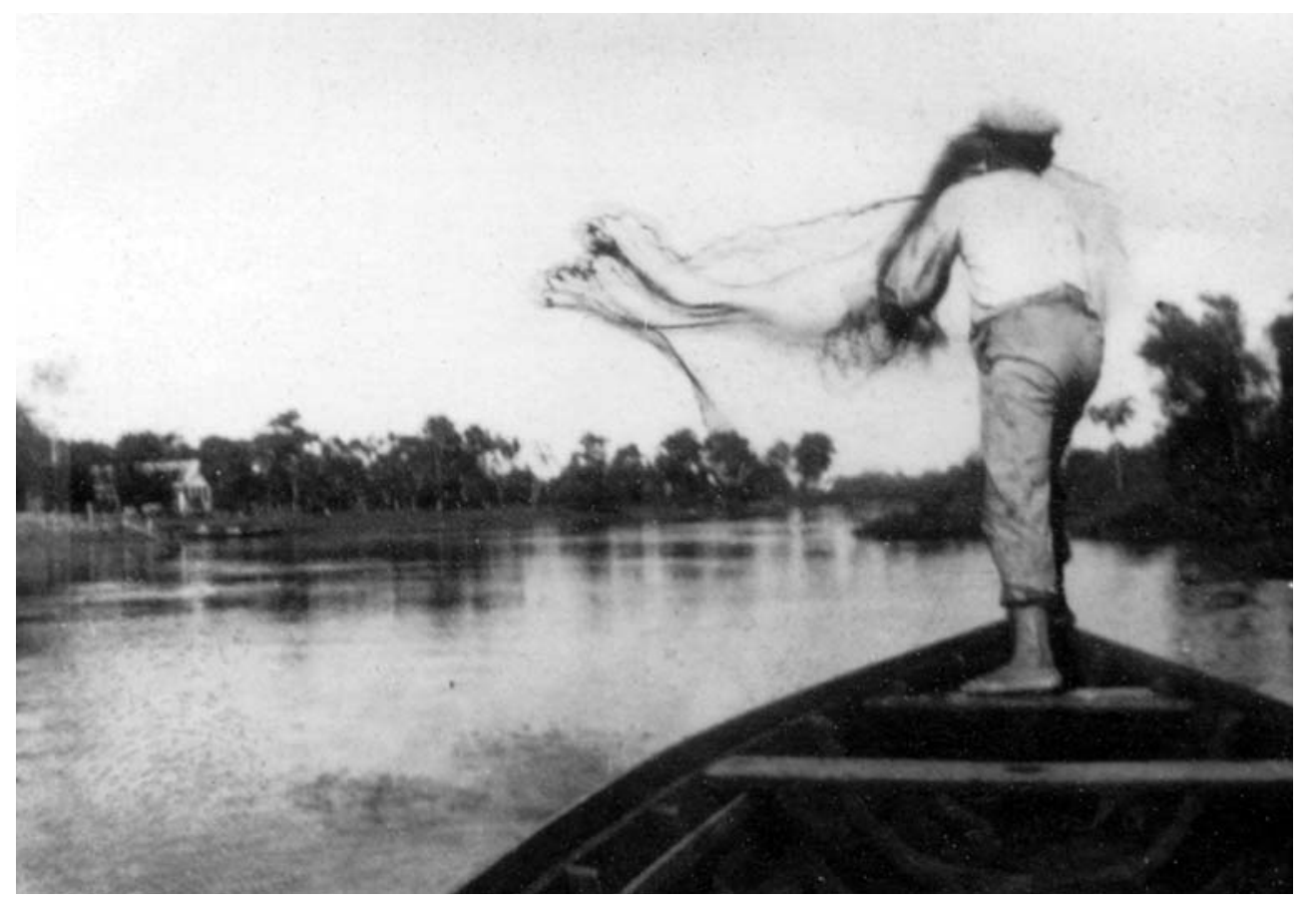

Figura 33 -"Atirando tarrafa/ Igarapé de Barcarena/ arredores de Manaus/ 7-VI-27" Inotação no verso). Acervo do Instituto de Estudos Brasileiros da Universidade de São Paulo.

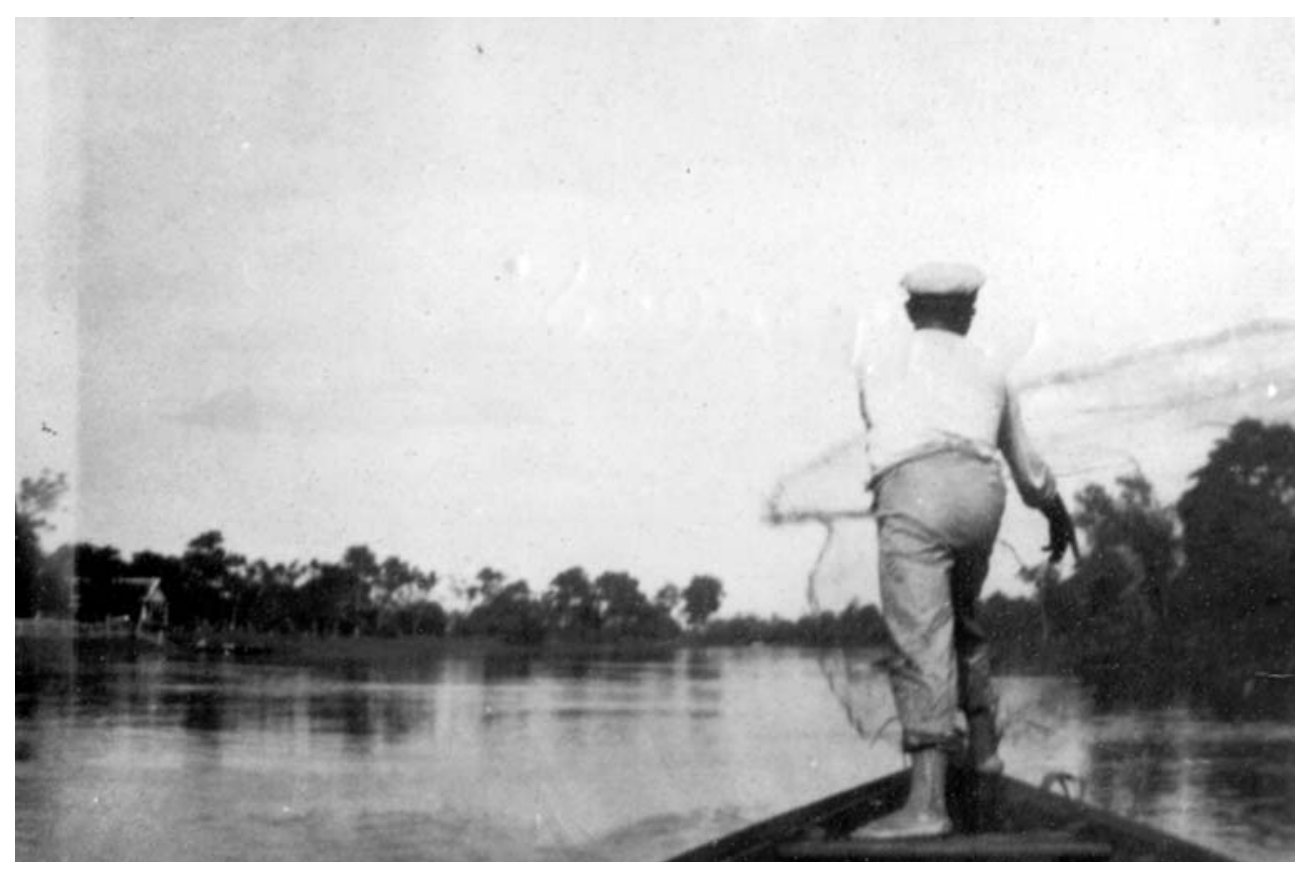

Figura 34 - "No furo de Barcarena (Manaus)/ Atirando a tarrafa 7-VI-27/ Tarrafeando" (notação no verso). Acervo do Instituto de Estudos Brasileiros da Universidade de São Paulo. 


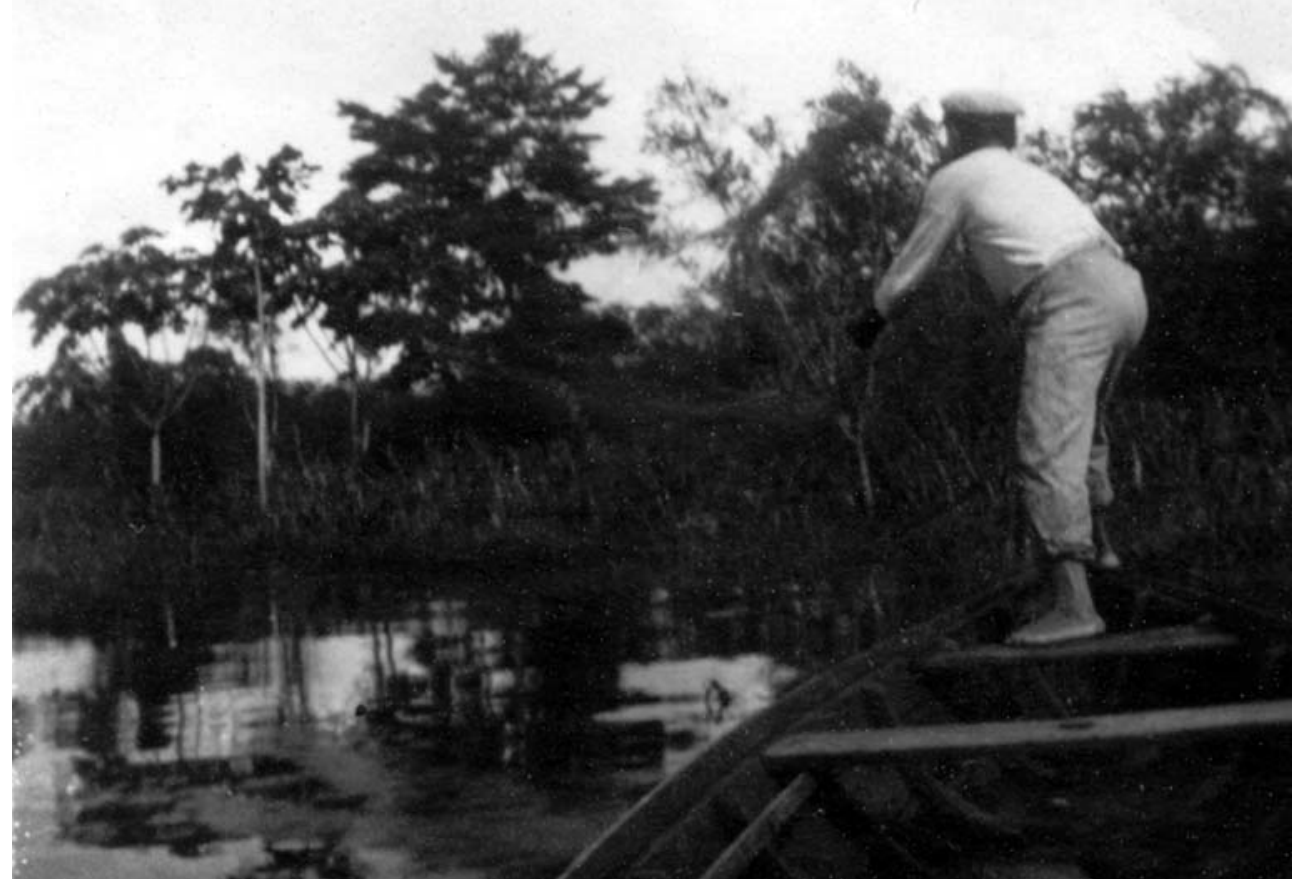

Figura 35 - "Tarrafeando/ Furo de Barcarena/ 7-VI-27" (notação no verso). Acervo do Instituto de Estudos Brasileiros da Universidade de São Paulo.

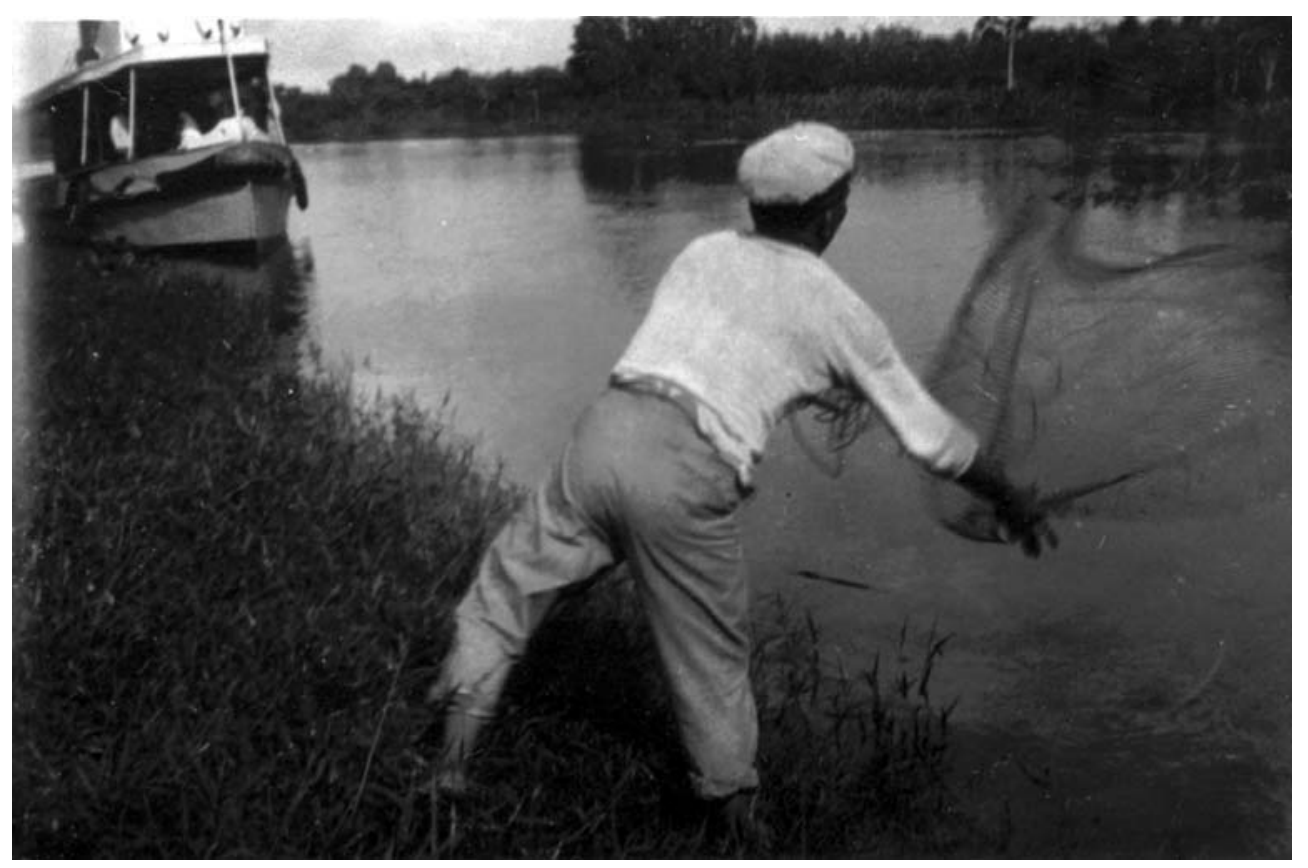

Figura 36 - "Tarrafeando a beira-rio/ Furo de Barcarena/ 7-VI-27" (notação no verso). Acervo do Instituto de Estudos Brasileiros da Universidade de São Paulo. 


\section{REFERÊNCIAS}

ANDRADE, M. Poesias. São Paulo: Martins, 1941.

. O Turista Aprendiz. Estabelecimento do texto, introdução e notas de Telê Porto Ancona Lopez. São Paulo: Duas Cidades/Secretaria de Cultura, Esportes e Tecnologia, 1976.

Será o Benedito? Crônicas do Suplemento em Rotogravura de O Estado de S. Paulo. Ed. preparada por Cláudio Giordano. São Paulo: Educ/Giordano/Agência Estado, 1992.

A arte religiosa no Brasil. São Paulo: IEB/Experimento/Giordano, 1993.

De São Paulo. Ed. anotada de Telê Ancona Lopez. São Paulo: Senac/Sesc, 2004.

BATISTA, M. R.; LIMA, Y. S. de. Coleção de artes plásticas Mário de Andrade. São Paulo: IEB, 1984.

COLI, J. Humano, demasiado humano. Ponto de Fuga. Folha de S. Paulo, São Paulo, (Mais!), $10 / 4 / 2005$.

EULÁLIO,A. A aventura brasileira de Blaise Cendrars. São Paulo: Quiron, 1978.

GIRARD, P. Le journal intime. Paris: PUF, 1963.

GEBARA, E. "Nunca olhei tão olhado em minha vida e está sublime": o (auto)-retrato de Mário de Andrade. In: SÜSSSEKIND, F; DIAS,T., (Orgs.) A historiografia literária e as técnicas de escrita: Do manuscrito ao hipertexto. Rio de Janeiro: Casa de Rui Barbosa/Vieira \& Lent, 2004.

GOMEZ-GÉRAUD, M. C.; ANTOINE, P. (Orgs.). Roman et récit de voyage: textes reunis. Paris: Presses de l'Université de Paris-Sorbonne, 2001.

GUIMARAENS FILHO,A. de. (Org). Itinerários: Mário de Andrade/Manuel Bandeira: cartas a Alphonsus de Guimaraens Filho. São Paulo: Duas Cidades, 1974.

LOPEZ, T. A. Mariodeandradiando. São Paulo: Hucitec, 1996.

As viagens e o fotógrafo. In: LOPEZ,T. A et al. Mário de Andrade fotógrafo e Turista Aprendiz. São Paulo: IEB/Vitae/ Safra, 1993.

MORAES, J.A. L. Apontamentos de viagem de São Paulo á capital de Goyaz, desta á do Pará, pelos rios Araguaya e Tocantins e do Pará á Corte: considerações administrativas e políticas. São Paulo: ed. do autor, 1883.

MORAES, M. A. de (Org.). Correspondência Mário de Andrade E Manuel Bandeira. São Paulo: IEB-USP/Edusp, 2000.

SPIX, J. B. Von; MARTIUS, K. F. P. von. Reise in Brasilien auf Befehl Sr. Majestät Maximiliean Joseph I, Königs von Baiern in den Jahren 1817 bis 1820. München: M. Lindauer, 1823-1831 (3 v., atlas e 7 mapas).

MELLO, V. de (Org.). Cartas de Mário de Andrade a Luís da Câmara Cascudo. Belo Horizonte/Rio de Janeiro:Villa Rica, 1991.

Artigo apresentado em 08/2005. Aprovado em 09/2005. 